\title{
The Enforcement of Informal Contracts in the Later Middle Ages
}

\author{
William M. McGovern, Jr.*
}

The remedies provided by the medieval common law for enforcing oral contracts were deficient in several respects. Unless the plaintiff had a specialty - a writing under seal-many of the writs used in the earlier middle ages allowed the defendant to escape judgment by denying his liability under oath with eleven oath-lielpers, the practice known as wager of law. ${ }^{1}$ The action of covenant, which was used to enforce contracts to perform services or to convey land, normally could not be brought at all unless the plaintiff produced a specialty.

In the later middle ages new forms of action arose to which these limitations did not apply. The most important of these new forms of action was assumpsit, ${ }^{2}$ but there were others that appeared at about the same time and developed along parallel lines. According to the traditional view, these actions origmally "sounded in tort" and were not "regarded as actions of contract."3 Indeed, it has been suggested that some features "peculiar" to the modern common law of contract "were the product of distortion caused by the trespassory [tortious] origin of assumpsit." ${ }^{4}$ This Article argues that these new writs were not regarded as sounding in tort. Rather, the courts understood they were administering a law of contract, and the rules they applied were not substantially different from our own. Insofar as the common law of contract has peculiar features, they cannot be attributed to the supposed delictual origin of assumpsit. Nevertheless, courts occasionally treated these new actions as delictual as an excuse to circumvent the limitations of the older forms of action.

* Professor of Law, Northwestern University; Visiting Professor of Law, University of California, Los Angeles, 1971-72. A.B. 1955, Princeton University; LL.B. 1958, Harvard University.

Translations are those of the author.

1. See McGovern, Contract in Medieval England: Wager of Law and Effect of Death, 54 Iowa L. Rev. 19 (1968). See also text acconpanying notes 221-23 infra concerning wager of law.

2. A form of action for the recovery of damages for the nonperformance of a parol or unsealed contract. See text accompanying notes 49-55 infra.

3. J. Ames, Lectures on Legal History 130 (1913). See also O. Holmes, The COMMON LAW 275-77 (1881).

4. S. Milsom, Historical foundations of the Common LaW 316 (1969). 
Some of the new actions diverged from assumpsit in important respects. Whereas assumpsit was restricted by the limitations of privity of contract, in ejectment, ${ }^{5}$ trover, ${ }^{6}$ and actions on the Statute of Labourers, ${ }^{7}$ plaintiffs were able to sue persons who were not parties to the contract. While assumpsit and trover remained actions for damages only, in ejectment plaintiffs were ultimately awarded possession of the land claimed. This Article traces the developinent of the new writs and explains why these differences arose.

I

THE WRITS

A. The Old Writs

\section{Trespass}

In the first half of the 14th century, before assumpsit appeared, attempts were made to use the writ of trespass as a substitute for detinue $^{8}$ and covenant in order avoid wager of law in detimue and the requirement of a specialty in covenant. These attempts were usually unsuccessful because the writ of trespass alleged that the defendant had acted "with force and arms" (vi et armis) and "against the king's peace" (contra pacem regis), allegations that were inconsistent with the facts in most cases of breach of contract. ${ }^{\circ}$ Professor Milsom suggests that plaintiffs first avoided this difficulty by disguising suits against bailees by using writs of trespass that failed to state that the goods had been delivered to the defendant. ${ }^{10}$ But the use of this device inust have come to an end when it was held that a defendant in trespass could plead as a defense that the goods had been delivered to him by the plaintiff. ${ }^{11}$ A much simpler way to avoid the problem posed by the vi et armis and contra pacem phrases in trespass was to frame a writ that omitted them. An action of trespass brought before the sheriff in the county court did not include these allegations; consequently in the county court trespass would lie against a bailce who injured or refused to return goods that had been delivered to him. ${ }^{12} \mathrm{~A}$ similar

5. An action for the recovery of land. See text accompanying notes 37-40 infra.

6. An action for the recovery of damages for the conversion of personal prop-

erty. See text accompanying notes 64-67 infra.

7. 23 Edw. 3 (1349). See text accompanying note 22 infra.

8. An action against one who detained another's goods. 3 W. BLACKstone, COMMENTARIES *152 (1765) [heremafter cited as BlACKSTONE].

9. Anon., 39 Sel. Soc. 14, No. 39 (1313); Tanmbes v. Skegness, 31 Sel. Soc. 215 (1312); Toteshalle v. Orfevre, 86 Sel. Soc. 149 (1321). But cf. note 226 infra.

10. S. Milsom, supra note 4, at 249.

11. Anon., 13 Rich. 2 (Ames) 103 (1390); Y.B. Mich. 43 Edw. 3, f. 30, pl. 15 (1370).

12. 87 Sel. Soc. 177, No. 239; A. Fitzherbert, Natura Brevium $* 86 \mathrm{C}$ [hereinafter cited as F.N.B.] 
form of trespass, which did not allege force and arms or a breach of the king's peace, began to appear in the king's court in the latter half of the 14th century. ${ }^{13}$ This form of trespass, without vi et armis and contra pacem, was soinetimes described as trespass "on the case."14 Quite frequently, however, the Yearbooks are careless about distinguishing the two, referring to actions without these clauses simply as "trespass." 15

\section{Deceit}

Like trespass vi et drmis, the action of deceit in its original form was inappropriate for breach of contract. The defendant in deceit was alleged to have deceived not the plaintiff but the king's court. This would occur, for example, when the defendant made a false claim that he was on the king's business in order to get a writ of protection. ${ }^{16}$ The allegation of deceit of the king's court, like the alleged breach of the king's peace in trespass $v i$ et armis, was thought necessary to justify the jurisdiction of the king's court; ${ }^{17}$ the theory was that the court that had been deceived was the natural forum for hearing such a complaint. ${ }^{18}$ As with trespass, efforts were made in the 14th century to extend the writ of deceit to cover breach of contract. In 1311 a plaintiff alleged that the defendant had agreed to dismiss a suit against him, but later prosecuted it to judgment. The defendant objected that this was simply a breach of covenant, not a deceit against the court, and that the writ of deceit was therefore improper. ${ }^{19}$ No judgment is recorded; nonetheless, for some breaches of contract an action of deceit would lie, for example against an attorney who had "fraudulently absented himself" from appearing for a chent who had retaimed him.. ${ }^{20}$

\section{B. The New Writs}

In one sense, it is misleading to state that one form of action "arose out of another." The immediate source of any new writ was the clerk in chancery who framed it. ${ }^{21}$ We can only speculate as to

13. E.g., Y.B. Mich. 43 Edw. 3, f. 33, pl. 38 (1370).

14. E.g., Y.B. Trin. 46 Edw. 3, f. 19, pl. 19 (1373) (per Finchdean, C.J.). For an early reference to "trespass on your case" see Y.B. Trin. 21 Edw. 3, f. 26, pl. 21 (1347).

15. E.g., Y.B. Hil. 3 Hen. 6, f. 36, pl. 33 (1425).

16. E.g., Hothum v. Danyel, 45 Sel. Soc. 125 (1316).

17. S. Missom, supra note 4, at 317.

18. See Y.B. Mich. 22 Edw. 3, f. 11, pl. 5 (1348); Le VieuX Natura BreviuM f. $51 \mathrm{v}(1572)$.

19. Orm v. Orm, 63 Sel. Soc. 11 (1311).

20. Y.B. Mich. 22 Edw. 3, f. 11, pl. 5 (1348); accord, Registrum OMNIUM Brevium f. 113 (1595); F.N.B., supra note 12, at*96D; cf. A. KIRALFY, The Action ON THE CASE 219 (1951).

21. Assuming that the writs were prepared by the chancery clerks rather than the 
what precedents he had in mind when he prepared the writ. Nevertheless it is reasonably clear that the writs of trespass and deceit were the inost important antecedents of the forms of action used in the later middle ages to enforce informal contracts.

\section{Statute of Labourers}

Of the writs that were to be used in the later middle ages to enforce informal contracts, the first to appear was one founded on the "Statute of Labourers." The enactment on which this writ was based was not actually a statute but an ordinance promulgated by the King and Council in 1349 when the ravages of the Black Death prevented a meeting of Parkiament. This ordinance was the prelude to a long series of subsequent statutes that were designed not to enforce contracts but to restrict freedoin of contract and to keep wages down. The remedies established for the enforcement of this policy were for the most part executed locally by justices of the peace. The principal activities of the central courts under the statutes involved chapter 2 of the 1349 ordinance, which provided that if a servant who was retained in someone's service "withdrew froin said service without reasonable cause or permission before the end of the agreed term he shall undergo imprisonment."22 Soon after the ordinance was enacted it was interpreted as providing an action for dainages against servants who had left their jobs. ${ }^{23}$ These writs are called by various names in the Yearbooks: soinetimes "a writ on the Statute of Labourers,"24 sometimes "trespass on the Statute of Labourers,"25 sometimes just "trespass,"20 and once "covenant on the Statute of Labourers." 27 Whatever the name given to the action, the writ followed a standard form:

Whereas by the King and his council for the common advantage of his kingdom it is ordained that if a servant, retained in someone's service withdraws from said service without permission and reasonable cause before the eud of the agreed term he shall undergo imprisonment, [the defendant], lately a servant of [the plaintiff], retained in his service at Lullyngston, withdrew from such service before the end of the agreed term without reasonable cause or the permission of [the plaintiff], in contempt of the King and to the grievous loss of [the plaintiff] and against the form of the aforesaid ordinance. ${ }^{28}$

plaintiffs. Cf. Commentary, 87 Sel. Soc. cxxvi-cxxix. The writs that appeared in the later middle ages, unlike some earlier ones (General Introduction, 87 Sel. Soc. xv), have never been attributed to a named individual.

22. Statute of Labourers, 23 Edw. 3, \& 2 (1349).

23. See notes 24-27 infra.

24. Y.B. Hil. 46 Edw. 3, f. 4, pl. 10 (1372).

25. Y.B. Mich. 47 Edw. 3, f. 14, pl. 15 (1373).

26. A. FItZHERBERT, LA GRAUNDE ABRDGEMENT, Laborers 30 (1577).

27 Y.B. Mich. 45 Edw. 3, f. 15, pl. 15 (1371).

28. B. Putnam, The Enforcement of the Statute of Labourers, app. 420-21 
The draftsmen of the 1349 ordinance probably had agricultural laborers in mind; the ordinance referred to any "reaper, mower, or other workman or servant."20 It soon became clear, however, that actions on this provision were not limited to manual laborers. ${ }^{30} \mathrm{Al}-$ though the statutory provisions for compulsory service applied only to certain types of service, the prohibition against withdrawing from service during an agreed term was general in scope. Carpenters and tailors, for example, were not "constrained to serve," but "if they are retained and depart from their service within the term limited between them and their master, their master will have an action against them ... because the second article of the Statute is general for all servants retained."31 Certain types of service, however, were held to be outside the statute. For exainple, one who had agreed to serve as a chaplain was not covered since the statute applied to "labourers and artisans" whereas a chaplain was "the servant of God" and not "bound to sing [mass] every day he does not want to, for various reasons which lie on lis conscience." ${ }^{\prime 32}$ Another exception, more difficult to understand, was made for apprentices. ${ }^{33}$ Perhaps the courts felt that since apprenticeship was typically a fairly complex long-term arrangement, a written agreement should be required, whereas an action on the statute would lie on an oral retainer. ${ }^{34}$ Probably for the same reason, objections were raised to attempts to use the statute to enforce contracts of employment of over one year. ${ }^{35}$ Nonetheless, in 1395 an action on the statute was allowed on a 20 -year employment contract although the plaintiff produced no writing. ${ }^{36}$

\section{Ejectment}

In 1364 a plaintiff brought "a writ of trespass" against an abbott

(1908) [hereinafter cited as PutNam]. See also Registrum OMNIUM Brevium f. 189 (1595).

29. Statute of Labourers, 23 Edw. 3, § 2 (1349).

30. Putnam, supra note 28, at 186-87.

31. Y.B. Mich. 38 Hen. 6, f. 13, pl. 30 (1459). See also F.N.B., supra note 12 , at $* 168 \mathrm{E}$.

32. Y.B. Trin. 50 Edw. 3, f. 13, pl. 3 (1376). But cf. Y.B. Pasch. 46 Edw. 3, f. 14, pl. 19 (1372); PUTNAM 187-89.

33. Y.B. Pasch. 9 Hen. 6, f. 7, pl. 18 (1431); Y.B. Mich. 39 Edw. 3, f. 22 (1365); Y.B. Mich. 45 Edw. 3, f. 13, pl. 11 (1371).

34. See Y.B. Hil. 21 Hen. 6, pl. 18, at f. 32 (1443) ("The making of an apprentice" involves "various covenants by nature which are to be performed, some by the master, some by the apprentice, so that ... the making of an apprentice hes in writing").

35. Y.B. Pasch. 29 Edw. 3, f. 27 (1355); Y.B. Mich. 45 Edw. 3, f. 13, pl. 11 (1371).

36. A. FITZHERBERT, supra note 26, at Laborers 58. 
who "had leased two mills to the plaintiff for a term of 10 years, and during the term the abbot came with force and arms and ousted him wrongfully." ${ }^{37}$ In the 15th century, writs in this form came to be known as ejectment or ejectio firmae. ${ }^{38}$ The writ required that the defendant show "why he with force and arms entered a messuage and a hundred acres of land with appurtenances in $A$ which [the defendant] demised [to the plaintiff] for a term which had not yet expired, and ejected [the plaintiff] froin his farm." ${ }^{39}$ In later times ejectment was used by freeholders to recover land, the action being brought in the name of a fictitious lessee for years. However, it could not normally be used to enforce a contract to convey a freehold, since the plaintiff had to have a right of entry on the land in orcler to bring ejectment. ${ }^{40}$

\section{Innkeepers}

In 1367 a writ was brought that alleged:

whereas according to the law and custom of the kingdom innkeepers who keep common inns for lodging men passing through parts where such inns exist are bound day and night to guard such goods of persons lodging therein as are within the inn without loss or theft so that no loss in any way shall befall such lodgers through the default of the innkeepers or their servants;

certain malefactors with force and arms by night broke into the room in which [the plaintiff] . . . was lodging within [the defendant's] inn at Huntingdon by default of [the defendant] and took and carried away goods and chattels of [the plaintiff] to the value of 4 pounds found therem . . . and inflicted other enormities on him . . . 41

Writs of this type had no special name; they are sometimes called "trespass" and soinetimes "trespass on the case" in the Yearbooks. ${ }^{42}$ The idea that innkeepers occupy a special status was borrowed from the civil law, which had an action against the master of an inn, ship, or stable for losses arising from the misdeeds of his employees. ${ }^{43}$ But whereas the Roman law action was not confined to innkeepers, in Eng-

37. Y.B. Mich. 38 Edw. 3, f. 33 (1364).

38. E.g., Y.B. Pasch. 1 Hen. 5, f. 3, pl. 3 (1413). As early as 1383 ejectment is spoken of as a separate writ, but its affinity with trespass is clear. "Eiectione firmae is only an action of Trespass in its nature." A. FitzaterberT, supra note 26, at Eiectione Firme 2.

39. W. Rastell, A Collection of ENTREes f. 243v, pl. 5 (1566) [hereinafter cited as RASTELL].

40. 3 BLACKSTONE $* 201$.

41. A. KIRALFY, supra note 20, at 222. The standard form of writ in Reoistrum OMNIUM BREVIUM f. 104 (1595) is quite similar.

42. Y.B. Hil. 22 Hen. 6, f. 38, pl. 8 (1444); Y.B. Mich. 22 Hen. 6, f. 21, pl. 38 (1443); Y.B. Hil. 11 Hen. 4, f. 45, pl. 18 (1410).

43. INSTITUTES 4.5.3; Digest 44.7.5.6. See also the French C. Civ. arts. 1952, 1953, 1782 (69e ed. Petits Codes Dalloz 1969-70). 
land writs against persons engaged in other "common" callings, such as common carriers, did not appear until the 17 th century. ${ }^{44}$ Although there are references in legal hiterature and the Yearbooks to common surgeons, smiths, and carriers, ${ }^{45}$ a writ of the innkeeper type was not framed agamst them, probably because it was unnecessary. Assumpsit could be used against one who had undertaken to cure the plaintiff or carry his goods. ${ }^{46} \mathrm{~A}$ writ could be brought against a smith alleging that the plaintiff had dehivered his horse to the defendant to be shod. ${ }^{47}$ But in the case of innkeepers plaintiffs would ordinarily have been unable to prove that the defendant had expressly promised to safeguard the goods in their rooms. Nor was the innkeeper exactly a bailee. As the defendant in the initial case of 1367 pointed out, the plaintiff had not dehvered the goods to him; the defendant had given the plaintiff a key so he could keep the goods in his room. ${ }^{48}$ Thus the situation was different from the one encompassed by ordinary actions against promisors and bailees, and a special writ was required.

\section{Assumpsit}

Yet another new writ-destined to be the most inportant of allappeared during the reign of Edward III. In 1369 a plaintiff alleged that:

whereas [the defendant] had undertaken [manucepisset] at London, for a suitable salary to be received therefor, to cure [the plaintiff's] finger which was accidentally injured, [the defendant] having taken a great part of his salary aforesaid performed his cure on the said finger so incompetently, negligently, or maliciously that [the plaintiff] lost a great part of his finger aforesaid.9

Although this writ said that the defendant manucepisset to cure the plaintiff's finger, soon afterwards the word assumpsit became standard to describe the defendant's promise or undertaking. ${ }^{50}$ From this

44. A. KIRALFy, supra note 20 , at 40,224 . But cf. Rastell f. $3 \mathrm{v}$ (action against a crane operator alleging a local custom); Pilk v. Venere, 46 Sel. Soc. xcv (1350) (action in Bristol against shipmaster alleging custom of England and the laws of Oleron).

45. Y.B. Hil. 19 Hen. 6, f. 49, pl. 5 (1441) (smith); Y.B. Mich. 9 Edw. 4, f. 31, pl. 4 (1469) (surgeon); Y.B. Hil. 22 Edw. 4, f. 49, pl. 15 (1483) (smith); C. ST. GERMAIN, DOCTOR AND STUDENT 221 (W. Muchall ed. 1874) (carrier) [hereinafter cited as DocTOR AND STUDENT].

46. Registrum OMNIUM BREVIUM ff. 105v, 108, 110, 111v, 112 (1595).

47. Id. at f. 106 .

48. Y.B. Pasch. 42 Edw. 3, f. 11, pl. 13, Anon., 82 Sel. Soc. 152-53, No. 103 (K.B. 1367).

49. A. KIRALFY, supra note 20 , at 224.

50. Skyrne v. Butolf, 11 Rich. 2 (Ames) 223, 227 (1388); REGISTRUM OMNIUM BREVIUM ff. 105v, 112 (1595). 
word the writ in postmedieval times acquired the name assumpsit. But assumpsit was slower than ejectment in acquiring a separate identity; ${ }^{61}$ in the middle ages it was usually referred to as "trespass" or "trespass on the case." ${ }^{2}$ Even as late as 1602, assumpsit was described simply as an "action on the case." "53

Assumpsit was a versatile form. It could be enployed mutatis mutandis against defendants who had "undertaken" to do anything for the plaintiff. In addition, during the 15 th century it became a vehicle for enforcing contracts to sell land, ${ }^{64}$ and in the 16th assumpsit began to be used to collect debts. ${ }^{55}$

\section{Warranty}

The next important writ in the history of contract did not appear until the reign of Richard II. In 1387 a writ alleged that the plaintiff had bargained with [the defendant] at Canterbury to buy a certain horse from him, [the defendant] knowing it to be subject to a certain infirmity, warranting it to be sound and suitable, falsely and fraudulently sold [it] there to [the plaintiff] for a great sum of money to [the plaintiff's] dainage. 58

The Register lists writs of this type under the heading of "trespass," ${ }^{27}$ and such actions are often referred to in the Yearbooks by that name or as "trespass on the case." 58 But such actions are also called "deceit" or "deceit on the case." Fi Fitzherbert, following nomenclature of the Yearbook reports, speaks of trespass on the case for breach of warranty in the sale of a horse or wine, ${ }^{00}$ and of a writ of deceit for a sale of fabrics, ${ }^{01}$ while Blackstone says that deceit and case are alternative remedies for breach of warranty. ${ }^{62}$ In fact, the form of writ was the saine whether the reporter chose to call the action deceit, tres-

51. See note 38 supra.

52. E.g., Y.B. Hil. 48 Edw. 3, f. 6, pl. 11 (1374); Y.B. Hil. 3 Hen. 6, f. 36, pl. 33 (1425). Sometimes assumpsit is referred to as "deceit." E.g., The Case of John Doige, 51 Sel. Soc. 97 (K.B. 1442).

53. Slade's Case, 76 Eng. Rep. 1074 (K.B. 1602).

54. See notes 197-211 infra and accompanymg text.

55. See notes 230-40 infra and accompanying text.

56. Garrok v. Heytesbery, 11 Rich. 2 (Ames) 4, 6 (1387). Cf. A. Frtzherdert, supra note 26 , at Monstrauns de faits 160.

57. Registrum OMNIUM BREVIUM ff. 96, 108, 111 (1595).

58. Y.B. Pasch. 7 Hen. 4, f. 14, pl. 19 (1406) (trespass); Y.B. 14 Hen. 6, f. 22, pl. 66 (1436) (trespass on his case).

59. Y.B. Trin. 11 Edw. 4, f. 6, pl. 11 (1472) (deceit); Y.B. Mich. 9 Hen. 6, f. 53, pl. 37 (1430) (deceit on the case).

60. F.N.B., supra note 12 , at $* 94 \mathrm{C}$.

61. Id. at $* 98 \mathrm{I}$.

62. 3 BLACKSTONE *165. 
pass, or case. Indeed, sometimes two different names are used for the action in the same report. ${ }^{63}$

\section{Trover}

The last action to appear did not arise until the 16th century. In 1555 a plaintiff alleged that he

was recently possessed as of his own goods of a certain gold chain worth 100 marks. And being thus possessed he by chance lost the chain at London . . . which chain afterwards came into the hands and posession of [the defendant] by finding . . . [The defendant] knowing the chain to be [the plaintiff's] chain, contriving craftily to defraud and deceive [the plaintiff] of the chain, sold the chain to various persons unknown to [the plaintiff] for various sums of money, and received the money for the same and converted the money to her own use and refused and still refuses to satisfy or content [the plaintiff] for the chain or its value to [the plaintiff's] damage of 100 marks. ${ }^{64}$

This action was called "case" in the early reports, ${ }^{85}$ but it eventually acquired a separate identity, as "trover," so called from the allegation that the defendant came into possession of the goods "by finding" (compare the French trouver-to find). This allegation was often a fiction; trover could be used against bailees to whom the plaintiff had dehivered the goods. ${ }^{66}$ The purpose of this fiction has never been satisfactorily explained. The allegation of a finding was obviously derived from a similar allegation that had become common in the 15 th century in actions of detinue for reasons that are equally mysterious. ${ }^{67}$

\section{II}

\section{TORT OR CONTRACT?}

Did the foregoing actions sound in tort or contract? This question is not entirely academic, because characterization frequently determines which rules will apply in a particular case. Today, for example, a court may need to determine which statute of limitations controls. ${ }^{68}$

63. Garrok v. Heytesbery, 11 Rich. 2 (Ames) 4 (1387).

64. No. 73, 123 Eng. Rep. 32 (C.P. 1555); cf. Rastell f. 4v.

65. E.g., Lord Mounteagle v. Countess of Worcester, 73 Eng. Rep. 265 (K.B. 1555); Fines v. Spencer, 73 Eng. Rep. 692 (K.B. 1571).

66. R. BROORE, LA GRAUNDE ABRIDGEMENT, Action snr le case 113 (1573); Isaack v. Clerk, 72 Eng. Rep. 941 (1614); 3 BLACKSTONE *152.

67. C. Fifoot, History and Sources of the Common LaW 32-34 (1949). Fifoot suggests that plaintiffs alleged a finding in order "to avoid allegations of violence" by the defendant. Id. at 33-34. But if plaintiffs wanted to avoid making "allegations of violence," they could simply have alleged that the goods "came into the defendant's hands" without saying how, the form of pleading that trover replaced.

68. E.g., Creighton v. Karlin, 225 So. 2d 288 (La. App. 1969); United States 
This distinction was not at issue in the middle ages, since there were no statutes of limitations in personal actions before $1623{ }^{\circ 9}$ However, in some situations medieval lawyers drew distinctions for purposes that are unimportant today.

\section{A. Venue}

A question of great importance in the middle ages was the place where the cause of action arose. Today an action can usually be brought where one of the parties resides, ${ }^{70}$ but in medieval law, since the jury was supposed to speak of its own knowledge, it had to be drawn from the neighborhood where the claim arose. ${ }^{71}$ In an action against a surgeon who promised to cure the plaintiff and treated him negligently, did the claims arise from the defendant's promise or from his negligence? In 1388 a plaintiff brought assumpsit against a doctor whose promise to cure was made in London, but whose negligent treatment occurred in Middlesex. The writ was challenged by the defendant because the action was brought in London although the tort allegedly occurred in Middlesex. The plaintiff argued that venue in London was proper because "the covenant took place" there, and the court agreed.72 Similarly, an action on the Statute of Labourers could be brought in the county where the defendant had been retained even though the departure from service had occurred in another country, for "this writ is taken on the covenant."73 The courts, however, showed some flexibility in classifying actions in order to avoid the technical requirements of venue. For example, in 1625 when a plaintiff won a verdict on a complaint alleging he lad lent the defendant a horse in London which the latter had converted in Exeter, the defendant contended that "the trial ought to have been at London, where the beginning of the contract was." But the court held that "the trial is good de vicineto de Exon, because the tort is supposed to be done there." "r4

Nevertheless, the contractual nature of the action was more commonly stressed. When a defendant denied that le had undertaken to

Fidelity \& Guar. Co. v. Truck \& Concrete Equip. Co., 21 Ohio St. 2d 244, 257 N.E.2d 380 (1970).

69. See An Act for Limitations of Damages, 21 Jac. 1, c. 16, § 3 (1623).

70. 28 U.S.C. $\$ 1391$ (1964); ILL. REV. STAT. ch. 110, \& 5 (1969); cf. Bick v. Haidle, 480 P.2d 818 (Mont. 1971).

71. J. Fortescue, De Laudibus Legum Anglie 42, 56 (S. Chrimes ed. 1942); Y.B. 17 \& 18 Edw. 3 (R.S.) 622 (1343).

72. Skyrne v. Butolf, 11 Rich. 2 (Ames) 223 (1388). In Y.B. Hil. 48 Edw. 3, f. 6, pl. 11 (1374) the writ was dismissed for failure to state where the assumpsit was made.

73. Y.B. Mich. 41 Edw. 3, f. 20, pl. 4 (1367). See also Y.B. Hil. 41 Edw. 3, f. 49 , pl. 2 (1367).

74. Whyte v. Rysden, 79 Eng. Rep. 623 (1625). 
cure the plaintiff's horse in London, the plaintiff argued that because the action sounded in tort, the defendant's plea was irrelevant: "He has killed my horse by his negligence, and that is the effect of my complaint, which he ought to traverse, and not the assumpsit." But the court disagreed; without the assumpsit the plaintiff would have no action, even if the defendant had been negligent. ${ }^{75}$

\section{B. Infancy}

In modern law, both civil and common, contract and tort are distinguished as to claims against persons under age; an infant or minor may be hable for a tort, though not for breach of contract. ${ }^{76}$ The problem of liability of minors during the middle ages was analyzed in terms of contract rather than tort under the Statute of Labourers. For example, in 1401 the defendant's counsel produced his client "to show the court the tenderness of her age," arguing that she was only ten years old and therefore could not make a covenant. Justice Hankford was unmoved by the plea since the statute merely referred to "able bodied"77 persons, but the other judges agreed that the defendant was "not able to make a covenant" and dismissed the action. ${ }^{78}$

\section{Agency}

Contract and tort are also distinguished with respect to the liability of an agent. An agent is not usually liable on a contract he executes on behalf of his principal, but an employee must answer for his torts even though committed in the service of his employer. ${ }^{79}$ Was breach of warranty a contract or a tort for purposes of this distinction? In the only reported medieval case that raises the problem, a majority of the court seems to have regarded the action as contractual. When the defendant pleaded that he had sold the goods as the servant of another, Chief Justice Brian thought this was a defense, "for it is the sale of the master, not of the servant." $"$ Justice Choke agreed:

75. Y.B. Hil. 19 Hen. 6, f. 49, pl. 5 (1441).

76. C. CIv. art. 1310 (69e ed. Petits Codes Dalloz 1969-70); Wisconsin Ioan \& Fin. Corp. v. Goodnough, 201 Wis. 101, 228 N.W. 484 (1930).

77. Actually the words potens in corpore appear only in the compulsory-service provision of the ordinance of 1349. Statute of Labourers, 23 Edw. 3, $\S 1$ (1349).

78. Y.B. Pasch. 2 Hen. 4, f. 18, pl. 7 (1401). See also Y.B. Pasch. 29 Edw. 3, f. 27 (1355). According to Fitzherbert, a child of twelve would be bound by his covenant to serve. F.N.B., supra note 12, at $* 168 \mathrm{D}$; cf. Y.B. Mich. 7 Hen. 4, f. 5, pl. 29 (1405); Edrich v. Quylter, 12 Rich. 2 (Ames) 108 (1388). The action of covenant itself lay against apprentices who were under 21 . 1 BLACKSTONE *466; cf. Y.B. Pasch. 9 Hen. 6, f. 7, pl. 18 (1431).

79. Restatement (SECOND) of Agency $\S \S 320,343$ (1958). The same distinction is made in the civil law. de Laizer v. Hamman, [1942] Receuil Analytique [D.A. Jur.] 126 (Cass. civ.) (France).

80. Y.B. Trin. 11 Edw. 4, f. 6, pl. 10 (1472). 
For this sale I will not have an action against the servant. If a man takes it upon himself to cure me of a certain malady . . . and then commands his servant to apply the medicine to me . . . whereby I am made worse, $I$ will not have an action against the servant but against the master. And so if one undertakes to shoe my horse and tells his servant who puts a nail in his foot, the action lies against the master. ${ }^{81}$

\section{Process}

More stringent enforcement procedures are sometimes applied in tort than in contract actions in modern law. For example, an Illinois statute provides that "no execution sliall issue against the body of the defendant except when the judgment shall have been obtained for a tort committed by such defendant. . .."82 Imprisonment of a defendant under this statute has been upleeld notwithstanding a constitutional prohibition against imprisonment for debt, which was held to apply only to actions on contract. ${ }^{83}$

A similar distinction appeared in medieval law, both as to the proeedure for compelling the defendant to appear and for executing any judgment against him. In a writ to trespass against the king's peace, a defendant who failed to appear could be arrested or outlawed. ${ }^{84}$ After judgment against him the defendant would be imprisoned until he had paid the damages assessed and a fine to the king. ${ }^{85}$ In actions of debt, on the other hand, the defendant was not subject to outlawry or imprisonment. Thus in 1321, during the London Eyre, when it was reported that someone had died in prison, the justices asked for what cause he had been imprisoned "since no one ouglit by right or law to be imprisoned for a debt." The sheriff justified the imprisonment by saying that the deceased had been "convicted of a trespass against the peace." pass was sometimes advanced as an argument against using the action in situations that did not involve a breach of the peace. Thus Chief Justice Bereford refused to allow the use of trespass for a breach of covenant inter alia because in trespass the defendant would be imprisoned. ${ }^{87}$ Along these lines a statute of 1344 provided that no one should

81. Id. See also 1 BLACKSTONE $* 431$.

82. IIL. REV. STAT. ch. 77, \& 5 (1969).

83. Petition of Blacklidge, 359 Ill. 482,195 N.E. 3 (1935).

84. 1 BRITTON 128-29 (F. Nichols ed. 1865); BRACTON's Note BOOK pl. 1232 (Maitland ed. 1887).

85. E.g., Anon., 82 Sel. Soc. 67, No. 43 (K.B. 1349).

86. 1 EYRE OF LoNDON, 86 Sel. Soc. 93-94 (1321). See also 1 BRITTON 132 (F. Nichols ed. 1865).

87. Anon., 39 Sel. Soc. 14, No. 39 (1313). See also Saxlingham v. Attewoode, 
be outlawed for a trespass that was not "against the peace." In 1368 , in the first recorded suit against an innkeeper, the plaintiff requested a writ for the arrest of the defendants. Chief Justice Knyvet denied the request without referring to the statute on the ground that although the defendants "are charged by the law, there is no kind of fault in them, and it would not be reasonable to put them in prison."

However, in many of the new forms of action used to enforce contracts, the defendant was subject to imprisonment. The Statute of Labourers provided for the offending servant's imprisonment. ${ }^{90}$ Writs of ejectment alleged that the defendant had acted "with force and arms" and "against the peace," and as a result defendants were subject to imprisonment in that action. ${ }^{91}$ Even in assumpsit, defendants were arrested in some cases. ${ }^{92}$

In the later middle ages the whole distimction between contract and tort with respect to process began to break down. In 1350 a statute authorized arrest and outlawry in the contractual action of debt. ${ }^{23}$ As a result plaintiffs sometimes used debt as a means to collect damages awarded in tort actions such as waste. ${ }^{94}$ Thus a defendant who had committed a tort was sued in a contractual form of action so that he could be imprisoned. The distinction between trespass against the king's peace and trespass on the case disappeared in 1503 when a statute provided "that lyke processe be hade hereafter in accions uppon the cas . . . as is in accions of trespas or dett." the change was to avoid the "grette delayes in accions of the case" by which "meny persones have ben putt frome ther remedye." The This probably refers to the avenues of escape afforded to defendants by medieval procedure. For example, medieval law did not ordinarily provide for a default judgment against a defendant who failed to appear; ${ }^{97}$ therefore, courts had to resort to arrest in order to compel the defend-

34 Sel. Soc. 142,147 (1312-13). Another difficulty was the contra pacem regis language of the writ. See cases cited note 9 supra.

88. Statute, 18 Edw. 3, stat. 2, c. 5 (1344).

89. Y.B. Pasch. 42 Edw. 3, f. 11, pl. 13 (1368).

90. Statute of Labourers, 23 Edw. 3, $\$ 2$ (1349). See also Rastell f. 168v, pl. 3.

91. F.N.B. *220H; A. Kiralfy, A Source Book of ENglish LaW 112 (1957).

92. A. KIRALFY, supra note 91 , at $187,192-93$.

93. Statute, $25 \mathrm{Edw} .3$, stat. 5, c. 17 (1350). Imprisonment in actions of account and for debts acknowledged under the Statute of Merchants goes back to the 13th century. Statute of Westminster II, 13 Edw. 1, c. 11 (1285); Statute of Marlborough, 52 Heu. 3, c. 23 (1267); Statute of Merchants, 13 Edw. 1 (1285).

94. Y.B. Hil, 43 Edw. 3, f. 2, pl. 2 (1369). See generally 3 BLACESTONE $* 160$.

95. Statute, 19 Hen. 7, c. 9 (1503).

96. Id.

97. T. Plucknett, A Concise History of the Common Law 386 (5th ed. 1956). 
ant's appearance. After judgment, although a writ would issue for collection of the damages from the defendant's goods, medieval law did not provide an effective remedy if the defendant had fraudulently conveyed them away. Thus imprisonment of the defendant was sometimes the only effective way to satisfy a judgment. ${ }^{.8}$

In modern times the distinction between the process available in tort and contract has also tended to disappear, but for a different reason. Now that effective means are available for obtaining and enforcing judgments, it seems mappropriate to imprison a defendant in any civil case whether tort or contract. Thus the above-mentioned Illinois statute has more recently been construed not to allow imprisonment even of a tortfeasor if he is unable to pay: "[T]he imprisonment of the judgment debtor depends upon the extent of his resources rather than the degree of his fault."

\section{E. Consideration}

In inodern times an action is sometimes characterized as sounding in tort in order to avoid the difficulties posed by the rule that a contract is unenforceable without consideration. ${ }^{100}$ According to the traditional view of legal historians, the early actions of assumpsit "sounded in tort," and therefore consideration "never played any part in the declaration." 101 I have argued elsewhere that this is not true although the word consideration does not appear prior to the 16th century. Nevertheless, usually in actions of assumpsit, and always in actions for breach of warranty, the writ alleged that the defendant had or was to receive something for his promise. ${ }^{102}$ Writs were sometimes challenged because they did not allege what we would call the consideration with sufficient particularity. ${ }^{103}$ Although these challenges did not succeed, we cannot infer from this that consideration was unnecessary; rather it seems to have been presumed. Even in those writs in which consideration was never alleged, it seems probable that a bargain with reciprocal obligations, rather than a gratuitous promise, was involved. Thus in ejectment, although the writ says nothing about rent, the typical

98. Y.B. Hil. 43 Edw. 3, f. 2, pl. 5 (1369) (per Thorpe, C.J.); cf. Statute of Fraudulent Conveyances, 13 Eliz. 1, c. 5 (1570). 464 (1969).

99. Lawyers Title of Phoenix v. Gerber, 44 Ill. $2 d$ 145, 149, 254 N.E.2d 461,

100. See, e.g., Carr v. Maine Cent. R.R., 78 N.H. 502, 102 A. 532 (1917).

101. J. AmEs, supra note 3, at 130. See also O. Holmes, supra note 3, at 196;

C. FIFoot, supra note 67 , at 397.

102. McGovern, Contract in Medieval England: The Necessity for Quid pro Quo and a Sum Certain, 13 AM. J. Legal Hist. 173, 191 (1969).

103. Y.B. Hil. 3 Hen. 6, f. 36, pl. 33 (1425); Y.B. Trin. 11 Hen. 6, f. 55, pl. 26 (1433); cf. Y.B. Mich. 7 Hen. 6, f. 1, pl. 3 (1428). 
lessee was paying rent; indeed, failure to pay rent was sometimes raised as a defense by the lessor. ${ }^{104}$ Similarly, writs under the Statute of Labourers are silent as to wages, but failure to pay wages was often alleged by the defendant as an excuse for his departure. ${ }^{105}$ Nor can we infer from the failure to allege consideration in the writ against innkeepers that the guest was staying in the inn without paying ${ }^{108}$-in fact, an innkeeper was permitted to retain the guest's belongings until he was paid for the rooin. ${ }^{107}$

The alleged delictual character of assumpsit has been given credit for liberating the law of debt from a supposed requirement that the promisor receive a benefit in order for the promise to be enforceable. According to Ames, "the gist of the action [in assumpsit] being the deceit . . . it was obviously unmaterial whether the promisor or a third person got the benefit of what the plaintiff gave up." 108 However, a benefit to the promisor was not necessary in the action of debt itself. $^{109}$ Therefore it is difficult to identify any difference between debt and assumpsit in this respect. More recently, in a curious turnabout, the "trespassory" origin of assumpsit has been blamed for the modern rule precluding past consideration. ${ }^{110}$ This theory is equally untenable. The idea that a promise to pay for service rendered in the past is actually a gift, subject to the requirements for an effective gift, is also found in the action of debt, ${ }^{111}$ and in French law. ${ }^{112}$ Indeed, the courts were more liberal in accepting past consideration in assumpsit than they had been in debt. ${ }^{113}$ It is difficult, therefore, to attribute current rules of consideration to anything in the history of assumpsit.

\section{F. Damages}

In tort actions the objective is to restore the plaintiff to the status quo; in contract the goal is to put the plaintiff in the position he would have been in had the contract been performed. Thus in contract a plaintiff is entitled to recover his anticipated profits, even if they exceed any out-of-pocket loss he has incurred. Williston states that "in

104. E.g., Y.B. Mich. 38 Edw. 3, f. 33 (1364).

105. A. FITZHERBerT, supra note 26, at Laborers 25, 30; Y.B. Mich. 28 Edw. 3, f. 21, pl. 18 (1354); Anon., 13 Rich. 2 (Ames) 31 (1389).

106. Compare the 1345 action in London against an innkeeper which does recite that the plaintiff was to pay $1 \frac{1}{2} \mathrm{~d}$. a week for his room. A. KIRALFY, supra note 20 , at 236.

107. E.g., Y.B. Hil. 22 Edw. 4, f. 49, pl. 15 (1483) (per Brian, C.J.).

108. J. AMEs, supra note 3, at 142. See also O. Holmes, supra note 3, at 285.

109. McGovern, supra note 102, at 181-83.

110. S. Mnsom, supra note 4, at 312-13.

111. Y.B. Pasch. 29 Edw. 3, f. 25 (1356).

112. A. von Mehren, The Civil Law System 656-58 (1957).

113. McGovern, supra note 102, at 196-97. 
the early law of assumpsit . . . the damages were based on the consideration given rather than on the value of the defendant's performance. Such a rule was natural when assumpsit was regarded as in the nature of a tort for deceit."114 Such a rule would have been "natural" if assumpsit was regarded as a tort, but there is no evidence that such a rule ever prevailed. To the contrary, buyers suing sellers for breach of warranty or for failure to deliver the property sold claimed damages far in excess of the price they had paid. ${ }^{115}$ Further, the theory of giving the plaintiff his lost profits was clearly articulated in some bills of assumpsit, in which the plaintiff complained that he lost inter alia "the great gain and profit which he by reason of the bargain and sale aforesaid should have had and enjoyed if [the defendant] had kept and fulfilled his aforesaid undertaking and promise."116

The damages recoverable in tort and contract actions also differ in certain other ways. Punitive dainages may be awarded for a tort, but not ordinarily for a breach of contract. ${ }^{117}$ And in both civil and common law, consequential dannages arising from a breach of contract cannot be recovered unless they were foreseeable at the time of the contract; this limitation is inapplicable to danages arising from a tort. ${ }^{118}$

Similar distinctions are reflected in an action of assumpsit brought in 1505. A majority of the court held that the action did not lie because the plaintiff could have sued in debt. Chief Justice Frowicke, however, thought that because the defendant had "deceived" the plaintiff he should be subject to suit in assumpsit:

[A]lthough Debt lies for the grain, still because [the plaintiff] has been deceived that is a greater wrong (tort) than the detention of the grain or the non-payment and for this [the defendant] cannot be punished in any action other than this one.... If I an bound on condition of paying a lesser sum and I deliver the lesser sum to my servant to pay it and he does not pay, in this case Debt lies or Ac-

114. $11 \mathrm{~S}$. Williston, A Treatise on the LAW of Contracts $\$ 1338$, at 201-02 (3d ed. 1968). See also J. AMEs, supra note 3, at 144-45. For a different view, see Washington, Damages in Contract at Common Law, 47 L.Q. REv. 345, $371-73$ (1931); cf. S. MILsom, supra note 4, at 285.

115. Garrok v. Heytesbery, 11 Rich. 2 (Ames) 4, 6 (1387); A. KIRuLFY, supra note 20 , at $227-28$.

116. RASTELl, supra note 39, at f. 7, p1. 9. See also id. at f. 6, pl. 6.

117. C. MCCoRmick, Handbook on the Law of Damages \& 81 (1935); Cal. CTv. CODE $\$ 3294$ (West 1970); cf. INSTTTUTES 4.6.17. However, a bad-faith refusal to perform a contract may be branded a "tort" in order to justify the imposition of punitive damages. See, e.g., Fletcher v. Western Nat'1 Life Ins. Co., 10 Cal. App. 3d 38, 89 Cal. Rptr. 78 (1970).

118. 5 A. Corbin, Contracts $\$ 1019$ (1964 ed.); Cal. Civ. Code $\$ 3333$ (West 1970); C. Crv. art. 1150 (69e ed. Petits Codes Dalloz 1969-70); Berillon v. Lavaulx, [1927] Recueil Périodique et Critique [D.P.] I. 105 (Cass. req. 1926). 
count for the non-payment. But because by the non-payment I have forfeited my bond, for this I have suffered a greater wrong (tort) and for this I will have an action on the case. ${ }^{110}$

Despite his reference to "punishing" the defendant, apparently Frowicke had consequential damages in mind; they are at issue in the hypothetical case he gives. Why could such damages not be recovered in debt? In modern law, consequential damages arising from failure to pay a debt to a third person (Frowicke's hypothetical case) are recoverable in an action sounding in contract. ${ }^{120}$ We know nothing about the basis on which damages were computed in actions of debt, but often very substantial damages were awarded in addition to the principal sum. ${ }^{121}$ In the writ of debt the sheriff was told to "command" the defendant to pay the debt, "and unless he did so," the sheriff was to summon him to appear in court. ${ }^{122}$ From this language Professor Milsoin has inferred that "since performance was primarily commanded, the defendant could avoid damages or other consequences by tendering performance."123 But in fact a defendant could avoid paying damages in debt only by proving he had tendered performance when it was due, or that he had "always been ready" to perform. ${ }^{124}$ Therefore it is hard to understand Frowicke's implication that appropriate damages could not be recovered in an action of debt. Perhaps the notion that consequential damages could not be recovered in debt was merely an excuse for plaintiffs to avoid the wager-of-law defense that was available to a suit in debt. ${ }^{125}$ This idea-that consequential damages could be recovered only in assumpsit-was to play an important part in the replacement of debt by assumpsit in the 16th century. ${ }^{126}$

Since evidence of the basis upon which damages were assessed in the middle ages is almost non-existent, conclusions can only be tentative. However, Williston's assumption that tort principles governed the measurement of damages in assumpsit is highly qustionable.

\section{G. Liability Without Fault}

Another distinctive feature of the law of contract in modern times is that fault is usually irrelevant to the liability of the promisor. Holmes observed that "when a man covenants that it shall rain tomorrow," he

119. Y.B. Trin. 20 Hen. 7, f. 9, pl. 18 (1505).

120. 11 S. Williston, A Treatise on the LaW of Contracts $\$ 1410$, at 606 (3d ed. 1968); C. MCCORMICK, supra note 117, at § 139.

121. E.g., Wolf v. Meggs, 78 Eng. Rep. 790 (Q.B. 1597).

122. REgISTRUM OMNIUM BREVIUM f. 139v (1595).

123. S. MIIsOM, supra note 4 , at 218.

124. Y.B. 11 \& 12 Edw. 3 (R.S.) 640 (1338); RASTELL f. 158; 3 BLACKSTONE *303.

125. Cf. McGovern, supra note 102 , at $187,201$.

126. See text following note 236 infra. 
must pay damages "if the promised event does not come to pass," because "the consequences of a binding promise at common law are not affected by the degree of power which the promisor possesses over the " promised event." 127

Holmes' statement would not hold true for the early action of assumpsit. The defendant was always alleged to have acted negligently in attempting the promised cure. "If a smith undertakes to guarantee [the cure of] my horse, and if by his negligence or neglect to cure within a reasonable time the horse is impaired, it is reasonable that he be [held] guilty. But if he does as much as he can, and applies himself diligently to the cure, it is not reasonable to hold him guilty even though [the horse] is not cured."128

In actions for breach of warranty an element of fault is found in the standard assertion in the writ that the defendant knew the goods were defective when he sold them. ${ }^{120}$ However, there is reason to believe that this allegation was a fiction, and the seller was liable whether or not he knew of the defect. Defendants never denied the allegation of knowledge in the writ; the regular plea in such cases was to deny making the warranty. ${ }^{130}$ In 1507 Chief Justice Frowicke implied that the seller's knowledge was irrelevant if he had warranted the soundness of the goods. ${ }^{131}$ However, the medieval courts refused to impose absolute liability for warranties of future performance in the sale of goods. According to Chief Justice Brian, if a seller "warrants that seeds will grow, such a warranty is void, for it is not in him to warrant that but in God."132 So also "if I sell a horse, and warrant that he will go 20 leagues in a day, if he does not do this [the buyer] will not have an action of deceit, for a warranty ought to be of something which is at

127. O. Holmes, supra note 3, at 299.

128. Y.B. Hil. 48 Edw. 3, f. 6, pl. 11 (1374) (per Cavendish, C.J.).

129. Occasionally a Yearbook report of a breach-of-warranty case contains no reference to scienter. E.g., Y.B. 14 Hen. 6, f. 22, pl. 66 (1436). However, in such cases the full writ probably did allege it. In post-medieval actions an express allegation of scienter was often omitted, but could be inferred from the general statement that the defendant sold "fraudulently." See Leakins v. Clizard, 83 Eng. Rep. 1082, 1090 (K.B. 1663).

130. Milson, Sale of Goods in the Fifteenth Century, 77 L.Q. REv. 257, 279-80 (1961). It is doubtful that a medieval court would have accepted a plea which put in issue the defendant's state of mind. As Chief Justice Brian said in another context, "it is common learning that the intent of a man will not be tried, for the devil has no knowledge of a man's intent." Y.B. Pasch. 17 Edw. 4, f. 2, pl. 2 (1478). Or, as Bracton more piously expressed it, "God alone examines a man's heart." $2 \mathrm{H}$. BRACTON, De Legibus et Consuetudinibus Angliae 130, 153 (G. Woodbine ed., S. Thorne transl. 1968) [hereinafter cited as BRAcron]. Elsewhere Bracton makes knowledge a relevant factor for various purposes, but generally in such instances he is following Roman texts rather than stating actual English law. Id. at 43, 136, 185.

131. Note, 72 Eng. Rep. 254, pl. 16 (1507).

132. Y.B. Trin. 11 Edw. 4, f. 6, p1. 10 (1472). 
the time of the warranty for [the seller] cannot warrant a thing which is to come."133

Perhaps this limitation can be ascribed to a view that the action sounded in tort. Sometimes the newer writs derived from trespass were contrasted with the older "contractual" forms of action. Thus Justice Paston said that "when someone is retained by me to buy a manor, if he does his duty to cause me to have the manor, although he cannot get it for me, I will not have an action [of assumpsit] against him." An agreement whereby the defendant "guaranteed to buy a manor for [the plaintiff] is clearly a covenant, and he ought to have an action of covenant for that."134 However, the suggested distinction between contract and tort was not consistently maintained. Even in the older contractual actions, the courts were reluctant to impose liability without fault. For example, in 1482 an action of debt was brought on a bond conditioned on compliance with an arbitration award. The defendant pleaded he had tendered the money payable under the award and had been refused. At first Chief Justice Brian thought this was no defense. "If a man is bound to me on condition that the Pope will be here at Westminster tomorrow, in this case if the Pope does not come, although there is no fault in the defendant, still he has forfeited his bond." But Justice Choke disagreed, "for if there is no fault in [the defendant] it is not reasonable that he be charged," and ultimately even the plaintiff's counsel acknowledged that the plea was valid. ${ }^{\mathbf{1 3 5}}$

A similar reluctance to impose liability without fault appears in an action of covenant brought against a lessee who had agreed to leave the premises in as good a condition as he found them. ${ }^{136}$ The defendant pleaded that the dainage of which the plaintiff complained was caused by a storm. The plaintiff contended that this was irrelevant under the terms of the lease, but the defendant insisted that he was responsible only for damage caused by his fault. The discussion that follows is inconclusive, but it is noteworthy that Justice Finchdean remarked that "if a man is bound by his deed to do a thing which is impossible to be done (although it is his folly) still the deed is void."137 Bracton states that lessees or bailees of personal property are responsible only if goods are lost by their carelessness. ${ }^{138}$ Most of the recorded

133. Id. (per Choke, J.).

134. Y.B. Trin. 11 Hen. 6, f. 56, pl. 26 (1433). See also Y.B. Hil. 11 Hen. 6, f. 18 , pl. 10 (1433) (per Babington, C.J.)

135. Y.B. Mich. 22 Edw. 4, f. 25, pl. 6 (1482). But cf. Y.B. Pasch. 33 Hen. 6, f. 16, pl. 7 (1455).

136. Y.B. Hil. 40 Edw. 3, f. 5, pl. 11 (1366).

137. Id. at f. 6. See also Loterych v. Atte Doune, 11 Rich. 2 (Ames) 211 (1388); Y.B. Pasch. 8 Edw. 4, f. 2, pl. 1 (1468).

138. 2 BRACTON 184, 284. (In order to have Bracton's text conform to the source 
medieval cases support this view; a defendant sued in detinue or account could plead that the goods or money entrusted to him had been taken by thieves or robbers. ${ }^{139}$ In the later middle ages there is some authority to the contrary, based on the theory that the bailee should be liable because he, in turn, had an action against the person who took the goods. ${ }^{140}$ This rationale did not impose absolute hability on bailees in all cases; where a remedy over was impossible they were not liable. ${ }^{1.11}$ Similarly, in actions of waste a distinction was drawn between damage from natural calamities, for which the defendant was not responsible, and damage from acts by third parties, for which the defendant was liable because he could sue the wrongdoer. ${ }^{142}$

In Roman law, although a bailee or lessee was not ordinarily liable without fault, he was absolutely liable if by the terms of the contract lie had assumed the risk of loss. ${ }^{143}$ Curiously, this notion does not appear in English law until almost the end of the middle ages. In 1388 when a defendant pleaded robbery in an action of account, the plaintiff replied that the defendant had received the money to carry "at his peril," but lie later waived this plea and instead alleged neghigence by the defendant. ${ }^{144}$ Perhaps he feared that the court would not accept the theory of absolute liability based on assumption of risk. In the following century, references to liability being dependent upon the terms of the bailment recur. ${ }^{145}$ In the 16th century, St. Germain states that although a bailee is normally liable only if at fault, if he "make a promise at the time of delivery, to redeliver [the goods] safe at his peril, then he shall be charged with all chances that may fall."140 This idea came to fruition in Southcote $v$. Bennet ${ }^{\mathbf{1 4 7}}$ in which it was held that theft of the goods was no defense for the bailee

because the plaintiff delivered the goods to be safe kept, and the de-

he is following or, indeed, to make sense at all, some emendation is required, such as Professor Thorne's translation suggests.) See also 1 BRITTON 156-57 (F. Nichols ed. $1865)$.

139. Bowdon v. Pelleter, 41 Sel. Soc. 136 (K.B. 1315); 29 Liber Assissarun f. 163 , pi. 28 (1345); A. FITZHERBERT, supra note 26, at Accompt 111; cf. Y.B. Mich. 10 Hen. 6, f. 21, pl. 69 (1431).

140. See Y.B. Hil. 33 Hen. 6, f. 1, pl. 3 (1455); Y.B. Trin. 3 Hen. 7, f. 4, pl. 16 (1488) (per Rede).

141. For example, the bailee could plead that goods were taken by the king's enemies who were not subject to suit. Y.B. Hil. 33 Hen. 6, f. 1, pl. 3 (1455).

142. Compare Y.B. Pasch. 29 Edw. 3, f. 33 (1355) with Y.B. Mich. 44 Edw. 3,

f. 44 , pl. 52 (1370). See also E. COKE, SeCOND INSTITUTES 303 (4th ed. 1671).

143. DIGEST 2.14.7.15; 19.2.13.5; 16.3.1.35.

144. Veel v. Wygryme, 11 Rich. 2 (Ames) 163, 164 (1388).

145. Y.B. Mich. 9 Edw. 4, f. 40, pl. 22 (1469); Y.B. Trin. 3 Hen. 7, f. 4, pl. 16 (1488).

146. Doctor AND STUDENT, supra note 45 , at 220 .

147. Southcote's Case, 76 Eng. Rep. 1061 (K.B. 1601). 
fendant had took it upon him by the acceptance upon such delivery, and therefore he ought to keep them at his peril . . . . ${ }^{148}$

The inference of an assumption of the risk of loss without fault from the general agreement of the bailee to keep the goods safely was criticized about a century later by Lord Holt. As he put it in Coggs $v$. Berndrd, ${ }^{149}$ "there is no reason or justice in such a case of a general bailment . . . to charge [the bailee] without some default in him."150 However, if a bailee does agree to assume all risks, it seems proper to hold him responsible for losses regardless of fault. It is surprising, therefore, that this idea was not more widely expressed im the middle ages.

Apparently the notion of responsibility without fault on the basis of a contractual undertaking was generally foreign to medieval ways of thought-witness the statement that a man cannot warrant that seeds will grow. ${ }^{151}$ Perhaps this is related to the idea (found also in modern law) that gambling contracts should not be enforced. ${ }^{152}$ The difference between a warranty that seeds will grow and a bet that they will is one of economic perspective. In some cases, insurance for example, the social utility of the "wager" justifies its enforcement. Recognition of the utility of certain types of wagers requires a degree of economic sophistication that was slow in coming to the common law courts. Thus for a long time the common law provided no adequate remedy for enforcement of insurance contracts. ${ }^{153}$

Recognition of the validity of contracts to assume risks gradually developed. An example of this developinent appears in an action in 1596 on a warranty that sheep sold would be "sound for the space of a year." The defendant relied on the old argument "that the action did not lye, because the warranty is impossible to be performed by the party, because it is onely the act of God to inake them sound for a year." But now the court ruled agaimst him, "for it is not impossible, no more then if I warrant that sucli a ship shall return safe to Bruges, and it is the usual course between merchants to warrant the safe return of their ships." 154 Southcote v. Bennet, ${ }^{155}$ decided a few years later, is part of the same trend. So also are the post-medieval cases holding

148. Id. at 1062 .

149. 92 Eng. Rep. 107 (K.B. 1703).

150. Id. at 110 .

151. See note 132 supra and accompanying text.

152. Restatement of Contracts $\$ 520$ (1932); C. Civ. art. 1965 (69e ed. Petits Codes Dalloz 1969-70) (France).

153. Insurance Co. v. Dunham, 78 U.S. (11 Wall.) 1, 31 (1870).

154. King v. Braine, 74 Eng. Rep. 899 (K.B. 1596).

155. Southcote's Case, 76 Eng. Rep. 1061 (K.B. 1601). 
that lessees were bound by a covenant to repair even though the damage resulted from a natural catastrophe. ${ }^{156}$

The contrast between the medieval and modern viewpoints is also illustrated by the history of the liability of persons engaged in a common calling. In 1703 Justice Holt states that whereas an ordinary bailee is bound "only to do the best he can," im the case of "one that exercises a public employment," such as a common carrier, "the law charges this person thus intrusted to carry goods, against all events but acts of God and of enemies of the King. For though the force be never so great, as if an irresistible multitude of people should rob him, nevertheless he is chargeable." ${ }^{157}$ This had not been the obligation of common innkeepers in the middle ages. Altlougl they liad been liable for the wrongs of their servants, ${ }^{158}$ vicarious liability for the fault of an einployee is not the same as liability without any fault. As in the civil 1 law, ${ }^{159}$ the writ against innkeepers regularly alleged that the plaintiff's goods lad been lost "through the fault" of the defendant or his servants. ${ }^{160}$ Although a mere general denial of fault by the defendant was not a good plea, various pleas showing special circumstances did excuse the innkeeper. ${ }^{161}$ In the first reference to common carriers in the 16 th century, liability was predicated on neghigence. ${ }^{102}$ But the idea of liability without fault took hold and Holt's dictum in Coggs $v$. Bernard ultimately became the law; in 1785 Lord Mansfield held that "a carrier is in the nature of an insurer" and is "liable for inevitable accident." 163

The modern trend toward imposing liability without fault has not been impeded by the "trespassory" origins of assumpsit and breacl of warranty. If anything, fault plays a smaller role in the common law of contract than in the civil law. For example, common law courts have held a physician liable on a promise to cure a patient even though he is not guilty of negligence. ${ }^{164}$ In French law, however,

156. Anon., 73 Eng. Rep. 72, No. 33a (K.B. 1533); Compton v. Allen, 82 Eng. Rep. 612 (1649); Bullock v. Dommitt, 101 Eng. Rep. 752 (K.B. 1796).

157. Coggs v. Bernard, 92 Eng. Rep. 107, 112 (K.B. 1703).

158. 42 Liber Assissarum f. 260 , pl. 17, 82 Sel. Soc. pl. 103 (1367). In this respect common innkeepers were peculiar, for the idea of respondent superior had not yet spread to other employers. See Doctor and Student 234-35.

159. INSTITUTES 4.5.3.

160. ReGistrum OMNIUM BreviUm ff. 104, 105 (1595).

161. See Y.B. Hil. 22 Hen. 6, f. 38, pl. 8 (1444); Y.B. Mich. 22 Hen. 6, f. 21, pl. 38 (1443); Calye's Case, 77 Eng. Rep. 520 (K.B 1584).

162. Doctor AND STUDENT 221.

163. Forward v. Pittard, 99 Eng. Rep. 953, 956-57 (K.B. 1785). See also David Crystal Inc. v. Ehrlich-Newmark Trucking Co., 314 N.Y.S.2d 559 (City Ct. N.Y. 1970).

164. Colvin v. Smith, 276 App. Div. 9, 92 N.Y.S.2d 794 (1949); Keating v. Perkins, 250 App. Div. 9, 293 N.Y.S. 197 (1937); McQuaid v. Michou, 85 N.H. 299, 157 A. 881 (1932). 
although a patient's claim against a doctor is classified as contractual (for purposes of the statute of limitations), ${ }^{165}$ the patient is required to show that the doctor was negligent. ${ }^{166}$ Also, in modern Anglo-American law knowledge by the seller is irrelevant in claims for breach of warranty, ${ }^{167}$ while under the Napoleonic Code if a seller is ignorant of the defects in the thing sold lis liability is limited. ${ }^{168}$ Thus the fact (if it is a fact) that actions of assumpsit or for breach of warranty originally "sounded in tort" lias not affected the development of hability without fault in our law of contract.

\section{III}

\section{OverComing the Obstacles to EFFective ENFORCEMENT OF INFORMAL CONTRACTS}

Although for most purposes the courts treated the new actions such as assumpsit as contractual, occasionally claims were regarded as delictual in order to avoid the limitations of the older contractual forms of action such as covenant and debt.

\section{A. Necessity for a Deed}

The crucial question raised by the new. writs when they first appeared was whether or not plaintiffs by using them could avoid the requirement of a specialty or deed (a writing under seal). This question created no difficulty as to writs on the Statute of Labourers, because the statute itself was thought to have abolished the need for a deed: "If my servant departs out of my service, at common law I will liave no action. The reason was because the contract between my servant and me sounds in the maimer of a covenant on which no action was given at common law without a specialty, and for this unischief was the statute ordained and an action given for that."169 Although there is nothing in the preainble of the ordinance of 1349 to indicate the draftsmen had this particular "mischief" in mind, ${ }^{170}$ actions on the statute based on oral agreements were allowed from the beginning without debate. ${ }^{171}$

In the other forms of action, however, objections were frequently

165. Soc. "Le sou medical" v. Sirot, [1963] D. Jur. I. 57 (Cass. civ. Ire) (note Esmein).

166. Bourdy v. Cerez, [1953] D. Somm. 75 (Pau); Docteur X v. Detrez, [1949]

D. Jur. 423 (Cass. civ.).

167. Williamson v. Allison, 102 Eng. Rep. 439 (1802).

168. C. Crv. art. 1646 (69e ed. Petits Codes Dalloz 1969-70); cf. Digest 19.1.13 pr.

169. Y.B. Mich. 11 Hen. 4, f. 24, pl. 46 (1409) (per Hankford, J).

170. Statute of Labourers, 23 Edw. 3, c. 2 (1349).

171. Cf. Y.B. Mich. 45 Edw. 3, f. 15, pl. 15 (1371). 
made to the effect that the plaintiff was trying to enforce a covenant without a deed. In 1364, for exainple, a lessor when sued in ejectment argued that the plaintiff "ought to show what he has of the lease." Chief Justice Thorpe overruled the objection. "He will not be forced to show a specialty if he is not demanding the term by way of covenant."172 Ten years later, however, a similar contention was accepted by Justice Finchdean, who said that the lessee "can have a writ of covenant against [the lessor] if he has a deed. And if he does not, it shall be accounted his own folly that he took an estate without a deed."173 Nevertheless, the lessor in that case "voluntarily waived his challenge" to the writ, ${ }^{174}$ and the right to brimg ejectment on an oral lease was apparently never questioned again. ${ }^{175}$

In the first recorded action for breach of warranty the defendant also raised the objection that the plaintiff was suing on a covenant and therefore "he ought not to have this action without a deed."178 But the objection was not allowed, no reason being given. ${ }^{177}$ Later it was suggested that the allegation of knowledge by the seller made the case distinguishable from an ordinary covenant. The buyer "cannot have an action on that warranty unless he shows the deceit; for upon the warranty by itself the action does not he without a specialty, because it sounds in covenant, and therefore it is necessary that he show a deceit precedent." 178

The suggestion that the delictual allegations in the writ distinguished the claim from one for breach of a covenant also appears in early actions of assumpsit. For example, in 1370 a defendant, when sued on an undertaking to cure the plaintiff's horse, objected that the plaintiff ought to have brought covenant; the plaintiff replied that we "could not have [an action of covenant] without a deed, and this action is taken because you performed your cure 'so negligently' that the horse died." 179

Why should the delictual allegations in the writ obviate the requirement of a deed? Under the Napoleonic Code the general requirement of a writing for obligations over 50 francs is inapplicable to claims arising from delicts, apparently on the theory that it is impossible for the

172. Y.B. Mich. 38 Edw. 3, f. 33 (1364).

173. Y.B. Hil. 48 Edw. 3, f. 7, pl. 12 (1374).

174. Id.

175. Cf. Y.B. Pasch. 1 Hen. 5, f. 3, pl. 3 (1413).

176. Garrok v. Heytesbery, 11 Rich. 2 (Ames) 4 (1387).

177. Id. at 5 .

178. N. Statham, Abridgement of the Law, Accions sur le cas 26 (M. Klingelsmith transl. 1915).

179. Y.B. Mich. 43 Edw. 3, f. 33, pl. 38 (1370). See also Bukton v. Townsend, Y.B. Mich. 22 Edw. 3, f. 38 (1348), reported in A. KIRALFY, supra note 91, at 187. 
victim of a tort to exact a writing from the tortfeasor. ${ }^{180}$ This rationale is inapplicable to the various medieval actions such as assumpsit. With the possible exception of the innkeeper cases, ${ }^{181}$ the plaintiff had voluntarily entered into dealings with the defendant, and therefore his failure to obtain a deed was his own folly. Another rationale may explaim why a deed was not required: the plaintiff's inability to prove the covenant by a deed was immaterial because the defendant had committed an actionable tort whether or not any contract existed. The difficulty with this explanation is that, as we liave seen, for many purposes, sucl as venue, these actions were treated as actions based on a covenant. ${ }^{182}$ It is therefore hard to see how the plaintiff's mability to prove the covenant by producing a deed could be regarded as irrelevant.

Perhaps the true explanation for these cases is that the judges wanted to avoid the requirement of a specialty in covenant because they thought it was a bad rule. This is certainly suggested by the remark of Justice Cavendish in an action of assumpsit in 1374: "[T] of covenant of necessity is maintainable without a specialty, because for sucl a small matter a man cannot always liave a clerk to make a specialty."183 Modern statutes that impose formal requirements for making contracts often exempt small contracts, ${ }^{184}$ but the requirement of a deed to bring an action of covenant had no such exception. Perhaps this was reasonable so long as the king's court was not considered a forum for small matters anyway, ${ }^{185}$ but as the king's court expanded its jurisdiction in the later middle ages, the requirement of a specialty in covenant became unreasonable.

Nonetheless, the rationale usually advanced in the 14th century for dispensing with a deed was that the action sounded in tort. ${ }^{186}$ This created a problem when, at the beginning of the following century, plaintiffs began to use assumpsit against persons who could not be charged with neghigence. In 1400 a plaimtiff sued a party who had

180. C. Crv. art. 1348 (69e ed. Petits Codes Dalloz 1969-70). Compare the medieval English rule that if a plamtiff had been compelled to contract with the defendant, the latter could not wage his law. McGovern, supra note 1, at 36-37.

181. See C. CIv. art. 1348, If 2 (69e ed. Petits Codes Dalloz 1969-70). Compare Justice Holt's reference to "the necessity" of dealing with common carriers as a reason for imposing absolute liability upon them. Coggs v. Bernard, 92 Eng. Rep. 107, 112 (K.B. 1703). Perhaps for this reason, dealings with persons exercising a common calling were not thought to "sound in covenant." Note, 72 Eng. Rep. 208, pl. 4 (1503). 182. See note 58 supra and accompanying text.

183. Y.B. Hil. 48 Edw. 3, f. 6, p1. 11 (1374).

184. C. Civ. art. 1341 (69e ed. Petits Codes Dalloz 1969-70); UnIform CoMMERCIAL CODE $\$ 2-201(1)$.

185. McGovem, The Enforcement of Oral Covenants Prior to Assumpsit, 65 Nw. U.L. Rev. 576, 578 (1970).

186. See text accompanying note 179 supra. 
failed to perform an undertaking to build some houses for him. The writ was dismissed, "because you have counted on a covenant and show nothing of it."187 The same result was reached in a similar case nine years later. ${ }^{188}$ In both cases the distimction was drawn between neghigence, for which assumpsit would lie, and nonfeasance, for which it would not. Negligence, for purposes of this distinction, included beginning to do the job but neglecting to complete it. Most historians assert that this distimction was maintained throughout the 15th century and that when, in 1506, any distinction between misfeasance and nonfeasance was clearly denied, ${ }^{189}$ this was "in defiance of all precedent." ${ }^{190}$ However, though the Yearbooks for the 15th century are not clear, there is much evidence indicating that the distinction between misfeasance and nonfeasance was abandoned not long after it first appeared. In 1425 assumpsit was brought agamst one who had failed to build a mill for the plaintiff as he had promised. ${ }^{101}$ The defendant did not even raise any objection on the point, but Justice Martin, sua sponte brought up the old argument that "no wrong (tort) is alleged in the writ by the doing of a thing, but only the nonfeasance of a thing, which sounds only in covenant."102 His colleagues, however, disagreed. According to Justice Babington, "Suppose that someone makes a covenant with me to cover my hall or a certain house within a certain time and does not cover it within that time . . . I will have a good writ of trespass on the matter shown against the one who made the covenant with me [and recover damages] for the nonfeasance."108 Justice Cokayne agreed and the defendant joined issue on a question of fact. ${ }^{104}$ A few years later Justice Paston, with the concurrence of Justice Juyn, said that if "a carpenter takes it upon himself to build me a house," or "a smith makes a covenant with me to shoe my horse," assumpsit would lie for failure to perform. ${ }^{195}$ Similarly in 1443, Justice Ayscoughe stated that "if a surgeon makes a covenant with me for a certain sum to heal my head," trespass on the case would lie "if he does not come to me and give me his medicines." 190

187. Y.B. Mich. 2 Hen. 4, f. 3, pl. 9 (1400).

188. Y.B. Mich. 11 Hen. 4, f. 33, pl. 60 (1409).

189. Y.B. Mich. 21 Hen. 7, f. 41 , pl. 66 (1506).

190. Salmond, The History of Contract, 3 Select Essays in ANglo-American LEGAL HISTORY 320, 327 (1909). Milsom finds "the steady trickle of writs in the [15th century] plea rolls alleging nonfeasances surprising" in view of "the clear answer of the Yearbooks." Milsom, supra note 130, at 257, 277. See also A. KIRALFX, supra note 20 , at 146.

191. Y.B. Hil. 3 Hen. 6, f. 36, pl. 33 (1425).

192. Id.

193. Id.

194. Id. at f. 37.

195. Y.B. 14 Hen. 6, f. 18, pl. 58 (1436).

196. Y.B. Pasch. 21 Hen. 6, f. 55, pl. 12 (1443). 
On the other hand, when the attention of the courts began to shift from such contracts to perform services to contracts to sell land, or to procure the land for the plaintiff, ${ }^{197}$ there was greater reluctance to give an action for mere failure to perform. Writs involving land contracts often charged the defendant with having "deceived" the plaintiff. Perhaps this phraseology was regarded as a counterpart to the allegations of negligence in the early actions of assumpsit, ${ }^{198}$ or of scienter in actions for breach of warranty ${ }^{199}$ - a device to give a delictual character to the writ in order to avoid the objection that a specialty was necessary. The deceit alleged in these writs consisted of the defendant's taking an action inconsistent with his promise; he had deceived the plaintiff by procuring the land for someone else, or by conveying the land to another. ${ }^{200}$ Such deceit was considered by some to be an essential element of the plaintiff's case: "If I retain someone to purchase a manor for me, although he does not do this, I will have no action agamst him without a deed so that I can have a writ of covenant . . . but if he becomes of counsel for another in this matter, because he has deceived me, I will have an action on my case." ${ }^{201}$ It was a complete defense for an alleged seller of land to deny that he had enfeoffed another, for without that the action could not be supported. ${ }^{202}$

How can this limitation be reconciled with earlier statements that assumpsit would he for mere failure to perform something the defendant had undertaken to do? Perhaps the distinction lies in the nature of the contract. When dealing with promises to procure or convey land, the courts were no longer dealing with small matters for which the requirenent of a specialty seemed mappropriate. When we consider that even today oral contracts to sell land are usually unenforceable, ${ }^{203}$ it is not surprising that the judges of the 15 th century hesitated to enforce them.

However, this theory does not explain the distinction between a seller who merely failed to perform his promise and one who conveyed to someone else. This may reflect the old distinction between mis-

197. The earliest examples are actions against agents who failed to procure the land. Y.B. Mich. 3 Hen. 4, f. 3, pl. 12 (1401); Y.B. Trin. 11 Hen. 6, f. 55, pl. 26 (1433); A. FITZHERBERT, supra note 26, at Accion sur le cas 44.

198. See note 38 supra and accompanying text.

199. See note 42 supra and accompanying text.

200. However, language about deceit was not always included. Rastell gives nine entries of assumpsit for failure to convey land. Five of them contain allegations of deceit; four do not. RASTELL, supra note 39, at ff. 5v-7.

201. Y.B. Hil. 11 Hen. 6, f. 18, pl. 10 (1433).

202. Y.B. Hil. 2 Hen. 7, f. 12, pl. 15 (1487).

203. E.g., IlL. REV. STAT. ch. 59, § 2 (1969); Bürgerliches Gesetzbuch [BGB] $\S 313$ (C.H. Beck 1967) (Germany). 
feasance and nonfeasance, ${ }^{204}$ but it is hard to see how a seller's conveyance of land to another is a tort, independent of any prior promise, in the same sense that neghigence in performing services might be viewed as a tort. The emphasis placed on the seller's conveyance to a third person appears "capricious," 205 and so it seemed to some judges at the time. According to Justice Ayscoughe, " [] $\mathrm{t}$ is all one case whether the defendant makes a feoffment to a stranger or whether he retains the land in his hand."200 In the same case, however, other judges argued assumpsit should lie when the seller had enfeoffed another, because covenant would not provide an adequate remedy even if the plaintiff had a deed: "Suppose that a man bargains to enfeoff me . . . and afterwards he enfeoffs another and then he reenters and enfeoffs me and the other ousts me, an action of covenant would fail because he has enfeoffed ine according to his covenant." 207

A second argument advanced in this case for giving relief suggests why a majority of the court was willing to enforce an oral contract to sell land even though it was not a "small matter." If a buyer of land defaulted, lee could be sued for the price in debt, even though the contract was oral, because in debt no specialty was required. ${ }^{208} \mathrm{~A}$ contract should bind both parties; it would be "mervelous ley" to have the buyer bound but not the seller. ${ }^{209}$ Under this rationale, however, a seller who retained the land was no different from one who had conveyed it to a stranger and an action ouglit to he in either situation. ${ }^{210}$. This view ultimately prevailed, and by 1506 it was accepted that

[i]f someone makes a covenant to build a house for me by a certain day and he does nothing about it, I will have an action on my case for this nonfeasance as well as if he had built it badly. . . . And so if someone makes a bargain with me that $I$ will have his land to me and my heirs for $20 £$ and that he will enfeoff me, if I pay him the $20 £$ and he will not enfeoff me according to the covenant I will have an action on my case. ${ }^{211}$

This "action on iny case" would allege that the defendant had undertaken (assumpsisset) to deliver seisin, and then, "slyly scheming to defraud" the plaintiff, had refused to do so. ${ }^{212}$ Although such allegations of fraud continued to be common form in actions of assumpsit

204. See Y.B. Mich. 3 Hen. 7, f. 14, pl. 20 (1487).

205. S. MILSOM, supra note 4, at 286.

206. The Case of John Doige, 51 Sel. Soc. 97, 98 (1442).

207. Id. at 99 (per Paston, J.).

208. McGovern, supra note 185 , at 579.

209. The Case of John Doige, 51 Sel. Soc. 97, 99 (1442) (per Newton, J.).

210. Cf. Y.B. Mich. 19 Hen. 6, f. 24, pl. 47 (1440) (per Newton, J.).

211. Y.B. Mich. 21 Hen. 7, f. 41, pl. 66 (1506).

212. RASTELL, supra note 39 , at f. 6, pl. 3. 
until the 19th century, ${ }^{213}$ deceit in this context came to be meaningless verbal abuse.

A modern counterpart is the allegation of fraud that has sometimes been used to avoid the prohibition in the Statute of Frauds ${ }^{214}$ against the enforcement of oral trusts and contracts to convey land. ${ }^{215}$ Here the allegation of fraud is not devoid of meaning; it requires the plaimtiff to prove not only a promise but an intention when the promise was made not to perform it. But what is the relevance of this fact? Perhaps it is thought that a lie is more heinous than a mere breach of promise. Yet, logically, the gravity of a charge ought not to reduce the quantum of proof necessary to support it. ${ }^{216}$ Ames reasoned that the distinction between fraud and failure to perform a promise honestly made was based upon the

distinction between a misfeasance and a nonfeasance, between a tort and a passive breach of contract. If a devisee fraudulently induces the devise to himself, intending to keep the property in disregard of his promise . . . he is guilty of a tort, and equity may and does compel the devisee to inake specific reparation for the tort by a conveyance to the intended beneficiary. If, on the other hand, the devisee has acquired the property with the intention of fulfilling his promise, but afterward decides to break it . . . he commits no tort, but a purely passive breach of contract. Equity should not compel the performance of this contract at the suit of the beneficiary, because the statute forbids. 217

But to many courts the distinction between misfeasance and nonfeasance seeuns no more persuasive in the 20th century than it did in the 16th. They have held that an oral trust of land can be enforced without alleging fraud, ${ }^{218}$ or that anyone who holds land contrary to his agreenent is "guilty of constructive fraud" which is sufficient to avoid the statute. ${ }^{219}$ With the development of various other judicially created exceptions to the Statute of Frauds, such as part performance and confidential relationship, the role of fraud as a means of circumventing formal requirements of the law of contract seems destined to dininish. ${ }^{220}$

213. See, e.g., 2 J. Chirtry, Pleading 44 (1809).

214. Statute of Frauds, 29 Car. 2 , c. $3, \S \S 4,7$ (1676).

215. See Charpentier v. Socony Vacuum Oil Co., 91 N.H. 38, 13 A.2d 141 (1940); 1 A. Scotr, TRUSTs $\$ 44.1$ (3d ed. 1967).

216. It is, however, not uncommon to require less proof when a defendant is charged with a more serious wrong. 4 BLACKSTONE $\approx 215$; T. ATkINSON, HANDBOOK OF THE LAW OF WirLs $\$ 56$, at 264 (2d ed. 1953). Compare the idea that a defendant charged with a crime or tort could not wage his law. McGovern, supra note 1, at $49-51$.

217. J. AMEs, supra note 3 , at $430-31$.

218. Strype v. Lewis, 352 Mo. 1004, 1009-10, 180 S.W.2d 688, 691 (1944).

219. Masino v. Sechrest, 268 Wis. 101, 109, 66 N.W.2d 740, 744 (1954).

220. In French law, the Code itself provides several avenues of escape from the 


\section{B. Form of Trial}

In actions of trespass the defendant's right to wager of law soon disappeared, ${ }^{221}$ and plaintiffs could insist that questions of fact be tried by jury. After brief hesitation, the same rule was applied in the actions such as assumpsit that were derived from trespass in the latter half of the 14th century. ${ }^{222}$ Beginning in the latter part of the 15th century, plaintiffs began to use assumpsit and other actions on the case as substitutes for detinue or debt in order to avoid wager of law by the defendant. $^{223}$ Plaintiffs who wished to obtain a jury trial by using case in place of detinue sought to show that their action sounded in tort. This was not difficult so long as they complamed that the defendant by his negligence or deliberate act had destroyed or damaged the goods entrusted to him. ${ }^{224}$ But if the defendant had merely detained the goods, it was at first thought that only detinue would lie: "If someone delivers goods to ine to keep and give back to him and I detain them, he will not have a writ of Trespass but rather a writ of Detinue . . . But perhaps if I burn them or break the seals or do some similar act, the action [of trespass] can be maintained."225 In a famous case of 1473 , a carrier who had broken into goods entrusted to him and "converted thein to his own use" was held to be guilty of a felony. ${ }^{220}$ This decision inspired the framing of writs on the case against bailees who had converted goods to their own use. In the first reported action of this type, Justice Choke was prepared to allow the action, but Chief Justice Brian agreed with the defendant that only detinue would lie. ${ }^{227}$ No judgment is reported here, but in 1504 the judges of the Common Pleas agreed that "where I bail goods [to someone] to guard, and he converts thein to his own use, an action on the case lies." ${ }^{28}$ What did it

formal requirements it imposes [see A. von MEHREN, supra note 112, at 619-28], so the claim of "fraud" as justification for enforcing informal contracts is unimportant.

221. McGovern, supra note 1 , at 50-51.

222. Id.

223. See, e.g., Y.B. Hil. 18 Edw. 4, f. 23, pl. 5 (1479).

224. See, e.g., Y.B. Hil. 2 Hen. 7, f. 11, pl. 9 (1486); Y.B. Mich. 12 Edw. 4, f. 13 , pl. 10 (1473).

225. Y.B. Trin. 33 Hen. 6, f. 27, pl. 12 (1455). Perhaps Littleton uses "Trespass" here as short for trespass on the case, as was common in the Yearbooks. See notes 13-15 supra and accompanying text.

226. The Case of the Carrier Who Broke Bulk, 64 Sel. Soc. 30 (1473). The idea that a bailee who breaks into a container entrusted to him commits a trespass is also found in the 14tb century. 87 Sel. Soc. 177 , No. 300; 87 Sel. Soc. 179, No. 316. See also Rattlesdene v. Gruneston, 54 Sel. Soc. 140 (1317).

227. Y.B. Hil. 18 Edw. 4, f. 23, pl. 5 (1479).

228. Y.B. Mich. 20 Hen. 7, f. 9, pl. 18 (1504). See also Y.B. Mich. 20 Hen. 7, f. 4, pl. 13 (1504); Simpson, The Introduction of the Action on the Case for Conversion, 75 L.Q. REv. 364, 376-78 (1959); Gumbleton v. Grafton, 78 Eng. Rep. 1011 (1598). In view of these authorities it is difficult to accept Professor Milsom's theory that the fictional allegation of a finding in trover was designed to make it appear 
mean to say that the defendant had converted the goods? In 1596 a jury, understandably confused by the allegation, asked whether a refusal to dehiver goods to the plaintiff amounted to a conversion. It was told that "the refusal was a conversion." 229 Thus the allegation of conversion, like the alleged deceit of a promisor in failing to perform his promise, came to be mere verbiage to justify the use of the form of action and added nothing to what the plaintiff had to prove.

The device of alleging a conversion did not work agamst a debtor, since he could not be said to have "converted" money which in legal theory became his when he borrowed it. ${ }^{230}$ Consequently, early in the 16 th century it was held that an action on the case could be used as a substitute for detinue and for covenant, but not for debt. ${ }^{231}$ To Chief Justice Frowicke, this seemed incongruous; since assumpsit would lie for nonperformance of a covenant, he felt it should also lie for nonpayment of a debt. ${ }^{232}$ But for the majority the availability of debt precluded the use of assumpsit; "where a general action lies, a special action on the case does not."233 Perhaps the courts were more willing to allow assumpsit as a substitute for covenant than as a substitute for debt because covenant was not an available alternative for a plaintiff without a deed. Plaintiffs avoided debt only because the defendant could wage his law in that action, and at first this was not considered a sufficient justification for resorting to assumpsit.

Since a writ describing the failure to pay a debt as a tort could not be framed, the line of attack pursued by creditors throughout the 16th century was to show that debt was not available to thein. This was easy in the case of a promise to answer for the debt of another, and actions of assumpsit were soon allowed against sureties on the theory that they could not be sued in debt. ${ }^{234}$ The same theory was extended to allow assumpsit against a debtor who had later promised to pay the debt: "Where a man is indebted to me and promises to pay before Michaelmas I can have an action of debt on the contract or an action of case on the promise . . . for no action of debt lies on the promise."235 The rationale that allowed this action of case, later known as indebitatus

that detinue would not lie against the defendant because he was a finder who had sold the goods. S. Mrisom, supra note 4, at 327-28. In fact, the availability of detinue was no bar so long as the defendant was alleged to have converted the goods.

229. Eason v. Newman, 72 Eng. Rep. 695, 78 Eng. Rep. 745 (C.P. 1595). But if goods had been pledged to the defendant, his refusal to return them until the debt was paid was not a conversion. Isaack v. Clark, 80 Eng. Rep. 1143 (K.B. 1614).

230. See 2 Bracton, supra note 130 , at 284.

231. Y.B. Mich. 20 Hen. 7, f. 8, pl. 18 (1504).

232. Id. at f. 9.

233. Id.

234. McGovern, supra note 102, at 194-95.

235. R. Brooke, supra note 66, at Action sur le case 5. 
assumpsit, seems to have been this: an action of debt could not be brought on the subsequent promise to pay because of the rule against past consideration. ${ }^{236}$ Nor was an action of debt on the original debt a sufficient remedy for the creditor, apparently because he could not recover consequential damages im debt. A statement to this effect by Chief Justice Frowicke in $1504^{237}$ was seized upon by later pleaders who alleged that, by reason of the debtor's failure to pay, their credit had been injured. ${ }^{238}$ In theory it was only compensation for these special damages that the plaintiff recovered in assumpsit; he remained free, after recovering his damages in assumpsit, to recover the debt itself im an action of debt. ${ }^{239}$ Whether many plaintiffs actually did recover two judgments on the same debt is doubtful. But the possibilities of unfairness to the debtor in allowing him to be sued twice were too great for this system to continue, and in Slade's Case it was resolved that "the plaintiff in this action on the case on assumpsit should not recover only damages for the special loss (if any be) which he had, but also for the whole debt, so that a recovery or bar in this action would be a good bar in an action of debt brought upon the same contract." 240

Slade's Case also held that assumpsit would he even without an actual subsequent promise to pay the debt. Although the plaimtiff could have brought debt, he was permitted to "have an action on the case, or an action of debt at his election." ${ }^{241}$ However, the decision in Slade's Case was clearly motivated by the deficiencies of wager of law, and the election given to plaintiffs to use assumpsit in place of debt did not apply to cases where the defendant could not wage his law in debt, such as debt on a bond or for rent. ${ }^{242}$

236. Y.B. Pasch. 29 Edw. 3, f. 25 (1356); Doctor AND STUDENT, supra note 45 , at 179.

237. See note 119 supra and accompanying text.

238. RAstell f. 4v, pl. 2, 3; Norwood v. Read, 75 Eng. Rep. 277, 278 (K.B. 1558); S. MIrsom, supra note 4, at 289.

239. Cf. Sturlyn v. Albany, 78 Eng. Rep. 327 (Q.B. 1587); Y.B. Hil. 18 Edw. 4, f. 23 , pl. 5 (1479) (per Catesby).

240. Slade's Case, 76 Eng. Rep. 1072, 1077 (K.B. 1602). See also Ashbrooke v. Snape, 78 Eng. Rep. 496 (Q.B. 1591).

241. Slade's Case, 76 Eng. Rep. 1072, 1075 (K.B. 1602). The King's Bench had begun to treat subsequent promise as a fiction many years before. Edwards v. Burre, 123 Eng. Rep. 310 (C.P. 1573) (dictum). The leading role of the King's Bench in the development of indebitatus assumpsit is often attributed to that court's desire to expand its jurisdiction. C. FIFoot, supra note 67, at 359; T. PlUCKNETT, supra note 97, at 644. However, the selfish interest of the King's Bench has been overstressed, since that conrt could and did entertain actions of debt in the 16th century by virtue of the rule that a defendant alleged to be in the custody of the marshall of the King's Bench could be sued there on any claim. See S. Milsom, supra note 4, at 58-59; RASTELL f. 177, pl. 1-3.

242. S. MILsOM, supra note 4, at 307; J. AMEs, supra note 3, at 168. 
As with the question of the necessity for a deed, the reported cases rarely touch upon what we would consider the merits of wager of law vis-à-vis trial by jury. Instead, plaintiffs attempted to show either that their case sounded in tort so that wager of law was inappropriate, or that for some other reason the action of debt was unavailable. In Slade's Case, however, all these obfuscations of the central question had disappeared. The principal objection to wager of law was, of course, that a defendant who was willing to perjure himself could escape hability. The major justification offered for wager of law was that the defendant might have paid the debt "in private," without witnesses. As long as defendants could not testify in a jury trial, this argument had merit and was not satisfactorily answered in Slade's Case. $^{243}$

\section{Formal Words}

"By the early law" of contract, according to Ames, "in the absence of the formal word, there was no liability." ${ }^{244}$ The principal example of this "unmoral doctrine" was the rule that an action for breach of warranty did not lie unless the seller had expressly warranted the quality of the goods sold; a mere assertion did not suffice. ${ }^{245}$

This rule did not come from "early law." Glanville in the 12th century and Bracton in the 13th say that if a seller sells goods "as sound" when they are not, he must take them back. ${ }^{248}$ For Glanville and Bracton the word "warrant" was not something a seller said but rather described what he was bound to do to protect the buyer's title. ${ }^{247}$ If the word was used at the time of a sale, it was in the future tense; the seller might say that he "will warrant" the property sold against all the world. ${ }^{248}$ The word "warrant" does not appear at all in the earliest recorded cases of buyers' complaints concerning defective goods. ${ }^{249}$

However, the writ for breach of warranty, which becaine standard in the later middle ages, invariably alleged that the defendant had sold the goods warantizando that they were sound, and the most common defense was a demial by the defendant that he had made such a war-

243. McGovern, supra note 1, at 51-52.

244. J. AMES, supra note 3, at 438-39.

245. Id.

246. R. Glanville, Tractatus de Legibus et Consuetudinibus Regni Anglie 130 (G. Hall ed. 1965) [hereinafter cited as GLANVILLE]; 2 BRACron, supra note 130, at 182.

247. Glanville 130; 2 Bracton 183.

248. 2 BRACTON 66-67.

249. See 2 Select Cases on the Law Merchant, 46 Sel. Soc. 48 (1278); 3 Select Cases, King's Bench pl. 97, 58 Sel. Soc. 179 (1307); The Court Baron, 4 Sel. Soc. 128 (1319); A. KIRALFY, supra note 20, at 237. 
ranty. ${ }^{250}$ An express warranty was held to be essential in the famous case of Chandelor v. Lopus, ${ }^{251}$ in which the defendant was alleged to have "affirmed" that the stone he sold the plaintiff was a bezar-stone. The court held that

the bare affirmation that it was a bezar-stone, without warranting it to be so, is no cause of action: and although he knew it to be no bezar-stone, it is not material; for every one in selling his wares will affirm that his wares are good, or the horse which he sells is sound; yet if he does not warrant them to be so, it is no cause of action. . . .252

Similarly, one who sold a term of years, affirming that it was worth $£ 150$, was not hable though it was worth less, "for it was but the defendant's bare assertion that the term was worth so much, and it was the plaintiff's folly to give credit to such assertion. But if the defendant had warranted the term to be of such value ... there it is otherwise; for the warranty given by the defendant is a matter to induce confidence and trust in the plaintiff." 253

These decisions should not strike us as "unmoral." Though modern law, like Roman law, does not require an express warranty for the seller to be hable, both systems recognize that not every statement by a seller im praise of his wares should give the buyer a claim. ${ }^{264}$ In the later middle ages the distinction between mere puffing and actionable misrepresentation was usually made by ineans of the simple test: did the seller "warrant" the statement complained of? But this test was not always controlling. One who sold corrupt food was liable without an express warranty. ${ }^{255}$ Also, a seller who sold goods that he did not own might be liable despite the absence of a warranty. ${ }^{206}$ In such cases, it was not considered folly on the part of the buyer to suppose that the food was wholesome or that the seller had the right to sell.

Even where a buyer had to allege a warranty, it is not clear how strict the requirements of proof were. It seems unlikely that a jury would return a verdict for a seller who had made material misrepresenf. 9.

250. See, e.g., Garrok v. Heytesbery, 11 Rich. 2 (Ames) 4, 6 (1387); RASTRLI.

251. 79 Eng. Rep. 3 (K.B. 1603).

252. Id. at 4.

253. Harvey v. Young, 80 Eng. Rep. 15 (K.B. 1602).

254. UNIFORM COMMercial CODE $\S 2-313(2)$; Digest 21.1.19. The word "warrant" was unknown to classical Latin.

255. Y.B. Mich. 9 Hen. 6, f. 53, pl. 37 (1430); Y.B. Trin. 11 Edw. 4, f. 6, pl. 10 (1472) (per Brian, C.J.); Note 16, 72 Eng. Rep. 254 (KB. 1507).

256. See Milsom, supra note 130, at 282; Kenrick v. Burges, 72 Eng. Rep. 483 (1583) (dictum); Dale's Case, 78 Eng. Rep. 308 (1585) (dictum). However, these cases do not go as far as later law in holding a seller to an "implied warranty" of title even though he says nothing and does not know the goods are not his. 
tations on which the buyer might reasonably have relied. True, the issue framed by the pleadings was whether the seller had sold the goods warantizando their quality. But presumably the parties would not have conducted their negotiations in Latin. What exactly was a seller who liad sold warantizando supposed to liave said in English? In actions for slander, where it was important to ascertain exactly what words the defendant had used, the Latin pleadings typically give these words in English. ${ }^{257}$ The absence of a similar practice in actions for breach of warranty suggests that the courts were not so meticulous about precise terminology here, and that a defendant might be lield liable for a representation seriously made even if he had not used words such as "warrant" or "guarantee."

Dean Ames also believed that plaintiffs had to prove an express promise by the defendant in actions against bailees who were not engaged in a common calling. ${ }^{258}$ Although there is some support in the sources for this view, ${ }^{250}$ the manifest weight of the evidence is against it. The Yearbooks and Register have actions without any assumpsit, which simply allege that the plaintiff had lent the defendant his liorse for a ride, ${ }^{200}$ or delivered a cliarter to him for inspection, ${ }^{261}$ or entrusted him with animals to guard. ${ }^{262}$ In none of these cases was the defendant engaged in a common calling. In some situations a plaintiff might choose between a writ that alleged an assumpsit by the defendant and one that did not. The Register has one writ reciting that the defendant assumpsit to guard the plaimtiff's sleep, and one that simply says that the plaintiff delivered his sheep to the defendant "for safe keeping" (custodiendas). ${ }^{263}$ Thus, unlike the stipulation of Roman law, ${ }^{264}$ the forins of contract known in medieval England did not require the use of any particular words in order to be enforceable.

\section{IV}

\section{Differences AMONG THE Forms of ACtion}

Althougl the forns of action used to enforce informal agreements

257. S. MrLSOM, supra note 4, at 334; RASTELL f. $12 \mathrm{v}$.

258. J. AMES, supra note 3, at 132. See also O. HoLMES, supra note 3, at 184; T. PlUCKNETT, supra note 97, at 638.

259. F.N.B., supra note 12, at $* 94 \mathrm{D}$; Mosley v. Fossett, 72 Eng. Rep. 746 (I596); Y.B. Hil. 19 Hen. 6, f. 49, pl. 5 (1441).

260. Registrum OmNium Brevium f. 106v (1595); Y.B. Hil. 21 Edw. 4, f. 79, pl. 24 (1482).

261. Registrum Omnium Brevium f. 106v (1595); Y.B. Hil. 39 Hen. 6, f. 44, pl. 7 (1461).

262. Registrum OmNium Brevium f. 107 (1595); Y.B. Mich. 12 Edw. 4, f. 13, pl. 10 (1473); A. KIRALFY, supra note 20, at 159.

263. ReGistrum OMNIUM Brevium ff. 107, 110 (1595).

264. Digest 45.1.2; $c f$. INSTITUTES 3.15.2. 
in the later middle ages evolved along similar lines, there were certain differences among them. The two most important of these involved the availability of a remedy against persons not parties to the contract, and the availability of specific performance.

\section{A. Remedies Against Third Persons}

Could a person to whom a promise was made sue persons other than the promisor or his heirs or personal representative? This question was answered differently in the different forms of action. Assumpsit was always limited by privity, but ejectment, trover, and actions on the Statute of Labourers were not.

It might appear axiomatic that contracts can have effect only between the contracting parties and cannot bind third persons. ${ }^{205}$ However, this difficulty can easily be circumvented by ascribing to the promisee a "property" right. Thus Blackstone explains that a master can sue one who has employed his servant because of "the property that every man has in the service of his domestics; acquired by the contract of hiring."206 But surely something deeper than the label underlies the recognition of such a right. A factor that is usually determinative in modern law is whether the third person had notice of the contract. Despite the master's supposed "property" in his servants, "if the new master did not know that he is my servant, no action lies" against him. ${ }^{267}$ Traces of this idea also appeared in medieval law, ${ }^{208}$ but the inability of the law courts to examine parties under oath ${ }^{200}$ made it difficult for thein to administer any test based on bona fides. In equity, on the other hand, the chancellor could examine the defendant, ${ }^{270}$ and the modern distimction between bona fide purchasers and others was generally applied. ${ }^{271}$

The action given to employers agaimst masters who retained their servants was based on the Statute of Labourers of 1349, which expressly provided not only that the servant should "undergo imprisonment," but also that "no one, under the same penalty, shall presume to receive or retaim in his service such [servant]."272 Even apart from

265. For statements of the general principle that a contract is not binding on nonparties, see C. Crv. art. 1165 (69e ed. Petits Codes Dalloz 1969-70); 3 BrActon 161.

266. 1 BlaCkstone *429. See also Biondet v. Granier, [1946] D. Jur. 18 (Cass. civ. 1945).

267. 1 Blackstone *429. See also Amatrudi v. Watson, 19 N.J. Super. 67, 99 A.2d 7 (1952); Code du TravaII liv. 1, art. 23a (33e ed. Petits Codes Dalloz 1965).

268. See note 275 infra and accompanying text.

269. See 3 BLACKSTONE *381-82.

270. Id.

271. See, e.g., note 288 infra and accompanyiug text.

272. Statute of Labourers, 23 Edw. 3, § 2 (1349). 
the statute, there was a common law action against a person who took away the plaintiff's servant, an action that remained in use particularly for apprentices, who were not covered by statute. ${ }^{273}$ Probably both the common law action and the provisions of the statute applicable to third persons were inspired by the idea that an action against the new employer was necessary to give effective relief since a judgment for damages against a servant or apprentice would often be uncollectible.

Although the statute made no exception for a master who hired another's servant without notice of the prior contract, in 1354 a defendant was allowed to plead that "he found [the servants] wandering out of the service of anyone and so hired them lawfully."274 A similar plea in a common law action for abduction of the plaintiff's villeins in 1376 inspired Chief Justice Belknap to remark that

if my villein flees out of my lordship or into another county and is wandering there out of the service of anyone, it is lawful for anyone to make him serve and until he is apprised that he is servant to another, or another's villein, he is not bound to make restitution . . . wherefore it seems that without alleging that you gave him notice, or that he had notice in some other inanner, you will not have an action against him. ${ }^{275}$

However, the difficulties in determining whether a defendant had notice were such that the courts later adopted a mechanical test. If the defendant retained the servant in the same county in whicl he had originally been employed by the plaintiff, the defendant could not plead that he had found the servant wandering out of anyone's service, "for [he] ought not to be ignorant of a thing within the same county," but if the second retainer took place in a different county the plea was good. $^{278}$

Even if the second employer had retained the servant without notice, he was given only limited protection; upon receiving notice he had to give up the servant. ${ }^{277}$ This may seem inconsistent with the protection afforded bona fide purchasers in modern law, but in fact it is not. Since the second employer (except in the unlikely event that he had paid the servant's wages in advance) would not have given value when

273. Y.B. Hil. 21 Hen. 6 , f. 31 , pl. 18 (1443); Y.B. Hil. 8 Hen. 6 , f. 28 , pl. 20 (1430); Registrum OMNIUM Brevium f. 109 (1595). It is not clear whether the "taking" alleged in the common law writ included persuading a servant to leave. See Y.B. Mich. 11 Hen. 4, f. 23, pl. 46 (1409).

274. Y.B. Mich. 28 Edw. 3, f. 21, pl. 18 (1354).

275. Y.B. Mich. 50 Edw. 3, f. 21, pl. 2 (1376). See also PUTNAM, supra note 28 , at 211.

276. Y.B. Hil. 17 Edw. 4, f. 7, pl. 4 (1478). See also Y.B. Pasch. 18 Edw. 4, f. 5 , pl. 25 (1478).

277. F.N.B. *168C; 1 Blackstone *429. See also CODE DU Travall liv. 1, art. 23a (33e ed. Petits Codes Dalloz 1965). 
he received notice of the plaintiff's rights, he would not actually be in the position of a bona fide purchaser. ${ }^{278}$

In a contract to sell property, the buyer can be given rights against persons other than the seller on the theory that title to the property passes when the contract is made. In the 13th century Bracton, following Rıman law, stated that ownership is not transferred to the buyer until the property is dehivered. ${ }^{279}$ In the later middie ages, however, the lavy shifted to the modern notion that in sales of personal property, "as soin as the bargain is struck, the property in the goods is transferred to the vendee." ${ }^{280}$ This change is usually attributed to the fact that the buyer's action was normally detinue: the "proprietary flavour" of the action of detinue "was strong enough to suggest the necessity, or at least the desirability, of attributing ownership to the party who sought to use it."281 However, a similar change, obviously not based on the logic of the English forms of action, took place in French law, which also provides that the buyer becomes the owner of the property as soon as the contract is made. ${ }^{282}$ Probably the attribution of ownership to the buyer was designed to achieve a result thought desirable- to give the buyer rights against third parties. This is suggested by the remark of Justice Choke in 1470 that "where I buy a horse . . . the property is in me by the purchase, so that if a stranger takes it I will have an action of trespass.."283

As to land, on the other hand, the courts refused to adopt the view that title passed upon the contract of sale: "If I buy a horse from you the property of the horse is in me now . . . but this is not so in our case, for although the plaintiff las the right to have the land in conscience, still the land will not pass without livery."284 Why did the courts distinguish between land and personal property? Perhaps they feared that the theory that title passed to the buyer when the contract was made would work an injustice on one who later bought the same land froin the seller before it was dehvered. In modern law a subsequent purchaser of either real or personal property left in the seller's possession may be protected if he buys in good faith, even though the

278. See C. Huston, The Enforcement of Decrees in Equity 123 (1915); UNIFORM COMMERCIAL CODE § 3-303.

279. 2 BRACTON 181; INSTITUTES 3.23.3.

280. 2 Blackstone *448. See also UNIForm Sales Act $\$ 19$, Rule 1.

281. C. FIFoot, supra note 67, at 229. See also S. MiLsom, supra note 4, at 228.

282. C. CIv. arts. 1138, 1583 (69e ed. Petits Codes Dalloz 1969-70).

283. Veer v. York, 47 Sel. Soc. 163 (1470). The theory that title passes to the buyer creates problems. Can he therefore take the horse before he pays for it? Choke dismissed this problem with the remark that "I do not speak to that purpose." Id. See also Y.B. Pasch. 17 Edw. 4, f. 1, pl. 2 (1478); Uniform Sales Act § 53.

284. The Case of John Doige, 51 Sel. Soc. 97, 101 (1456). 
seller no longer has title. ${ }^{285}$ However, as we have seen, the common law courts, powerless to examine a defendant on oath, were reluctant to attempt to determine his bona fides. By maintaming the theory that ownership remained in the seller until the land was delivered, a subsequent purchaser who received the land from the seller was protected; the buyer's only remedy was an action for damages against the seller. ${ }^{286}$ In the case of personal property, on the other hand, a bona fide purchaser could be protected even though he bought from a seller who no longer had title to the goods, because a sale of goods in an open market gave title to the buyer even thougl the seller had none. ${ }^{287}$

In equity, the chancellor could examine the defendant and was therefore prepared to inquire into his good faith. If a feoffee to uses "makes a feoffment over [to one] who knows . . . that his feoffor was enfeoffed" in trust, the second feoffee would be compelled to restore the property to the beneficiary. ${ }^{288}$ Apparently the chancellor would also give relief to a buyer of land against a subsequent purchaser from the seller who had notice of the contract. ${ }^{289}$ From this the conclusion could be drawn that in equity title to land did pass to the buyer when the contract was made-that "where one is seised to his own use, if he sells the land, by force of the sale he will be said to be a feoffee to the use of the one who bought it." ${ }^{290}$ In 1535, the Statute of Uses provided that if any person stood seised of land to the use of another "by reason of any bargayne, sale . . . covenaunte, contracts, agreement" or otherwise, the legal title should pass to the cestui que use. ${ }^{291}$ By itself, this provision would have created great injustice. The law courts, making no distimction between bona fide and mala fide purchasers, would have vindicated the legal title conferred on buyers by the Statute of Uses against anyone. In order to avoid this, Parliainent in the same year passed the Statute of Enrollments, which stated that no lands

285. Uniform Sales Act \$ 25; C. Crv. art. 1141 (69e ed. Petits Codes Dalloz 1969-70).

286. Statute of Wales, $12 \mathrm{Edw} .1, \S 10$ (1285). For a similar sensitivity to the rights of a bona fide purchaser from the possessor of land see GLANVILLE, supra note 246, at 123-24. However, medieval law gave no protection to a bona fide purchaser of land that had been charged with a rent. Y.B. 33-35 Edw. 1 (R.S.) 70 (1305-07); Anon., 80 Sel. Soc. 286, Nos. 256-57 (circa 1300).

287. The courts seem to have regarded one who bought outside a market overt as ipso facto not a bona fide purchaser. See Case of Simon Eyre, 51 Sel. Soc. 114 (Ex. 1456); Bishop of Worcester's Case, 72 Eng. Rep. 629 (K.B. 1595).

288. Y.B. Pasch. 7 Hen. 7, f. 12, pl. 2 (1494) (per Chancellor); cf. A. FITzHERBERT, supra note 26, at Sub pena 19; Y.B. Mich. 5 Edw. 4, f. 7, pl. 16 (1465).

289. Barbour, The History of Contract in Early English Equity, in 4 OxroRo StUdies in Social aNd Legal History 199 (1913).

290. Y.B. Hil. 21 Hen. 7, f. 18, pl. 30 (1506). See also Doctor AND STUdENT, supra note 45 , at 170.

291. Statute of Uses, 27 Hen. 8, c. 10, § 1 (1535). 
"shall pass, alter or chaunge frome one to another . . . by reason oonly of any bargayne and sale thereof, excepte the same bargayne and sale be made by writing indented sealed and enrolled" in a public office. ${ }^{202}$ Unfortunately, this statute did not provide the complete protection to bona fide purchasers that was intended, since it failed to cover all of the contracts that, under the Statute of Uses, passed title to the promisee without delivery of the land. ${ }^{203}$

If land was leased for a term of years, even a lessee in possession did not have a freehold protected by the older forms of action used to recover land such as novel disseisin. ${ }^{294}$ His contract with the lessor could be enforced by an action of covenant, but covenant would not lie against third parties, because "the obligation of a covenant can not bind others." ${ }^{295}$ It was soon recognized that a right to sue only the lessor did not give the lessee adequate protection, since the lessor might be unable to pay damages. Therefore, a new writ, quare ejecit, was invented, which lay agamst persons to whoin the lessor sold the land.200 But quare ejecit gave no rehef against a third person who ejected a lessee without a sale from the lessor. In such a case the lessor was expected to sue the third person, whose ejectment of the lessee constituted a disseisin to the lessor. However, by 1313 the courts had allowed a lessee to sue any third person who ejected him. ${ }^{207}$ All this had been settled before the writ of ejectment arose in the latter part of the 14th century. The plaintiff's objective in the early actions of ejectment was not to obtaim relief against third persons, but rather to get damages from the lessor despite the absence of a specialty to prove the lease. ${ }^{298}$ But ejectment by its terms lay against anyone who ejected the lessee and was later used against persons who were not parties to the lease, including purchasers from the lessor. ${ }^{209}$ The courts were not

292. Statute of Enrollments, 27 Hen. 8, c. 16 (1535).

293. Sharington v. Strotton, 75 Eng. Rep. 454 (K.B. 1564); 2 Blackstone *338$39,342$.

294. 2 BRITTON 124 (F. Nichols ed. 1865). The reasons for this rule have never been satisfactorily explained. McGovern, supra note 185, at 612-13.

295. 3 Bracton 161.

296. 87 Sel. Soc. 93 , No. 187.

297. Goldynton v. Hardy, 34 Sel. Soc. 226 (K.B. 1312-13). See also 87 Sel. Soc. 285-86, No. 755.

298. In Y.B. Mich. $38 \mathrm{Edw} .3$, f. 33 (1364), only the lessor was sued. In Y.B. Hil. 48 Edw. 3, f. 6, pl. 12 (1374), the lessor was sued with another who did not appear. Possibly this third party joined as a defendant was a "John Doe," inserted to justify the lessee's failure to use covenant. The reporter notes that "this writ was brought against the lessor and another who was not a party to the lease so an action of covenant would not lie against him so that [the plaintiff's] writ of trespass was more readily mamtainable against the lessor."

299. In theory the proper action agamst a purchaser from the lessor was quare ejecit, but the courts nevertheless allowed ejectment. Pynchemore v. Brewyn (1481), reported in A. KIRALFY, supra note 91, at 110; 3 BLACKSTONE "207. 
concerned about bona fide purchasers in this situation, presumably because lessees, unlike buyers under executory contracts, had possession under the lease, which gave notice to the world of their rights.

Sometimes in connection with a transfer of land, the transferor would exact a promise from the transferee. If the agreement gave the transferor a right of reentry on the land upon nonperformance of the promise, the land was said to be obligated and would pass to third persons subject to this burden. Despite the rule that no one was bound by a covenant to which he was not a party, the original transferor could enter the land and rely on the covenant as a defense to a suit for disseisin by a third person, or could bring an action of covenant against any subsequent transferee of the land, including one who had no notice of the covenant. ${ }^{300}$ Thus, in 1317 when defendants asserted a right of entry under a deed given by their ancestor to one Roger, the plaintiffs objected that "we are strangers to the deeds that they allege and not at all privy to the conditions," but Chief Justice Bereford told them that "if the covenant was such as they say, the land passes with the condition into whosever hands it comes." ${ }^{\text {301 }}$ Covenants binding on nonparties were also recognized in connection with leases. If "a man leases a house and land for [a term] of years, and the lessee covenants that he and his assignees will repair the house, and then the lessee grants over his term and the assignee does not repair, an action of covenant lies against the assignee, for this is a covenant which runs with the land." 302

The notion that a covenant could run with the land seems inconsistent with the rule that one who covenanted to buy land had no rights at law against third parties. Perhaps the situations were distinguishable, however, on the basis that third persons, even when dealing with one in possession of the land, could and should inquire as to any rights reserved by someone in the chain of title.

Thus the medieval distinctions between contracts that bound third persons and those that did not seem to approximate, although imperfectly, the modern distinction between bona fide and mala fide purchasers. The approximation was complete in equity because of the chancellor's power to examine the defendant on oath.

\section{B. Specific Performance}

A notion that is familiar to every inodern lawyer is that a plaintiff must go into equity in order to obtain specific performance of a con-

300. 2 BRACTON 145-47.

301. Monnington v. Monkland, 61 Sel. Soc. 169, 173-74 (1317). See also 40 Liber Assisarum f. 241, pl. 13 (1366).

302. R. BROOKE, supra note 66 , at Covenant 32 . An assignee of the lessee was 
tract. Although Ames believed that the practice of granting specific performance did not become established until the 16th century, ${ }^{303}$ we now know that chancellors were ordering performance of contracts to convey land at least as early as the 15 th century. ${ }^{304}$ However, a 15thcentury lawyer would probably not have said that one goes into equity for the purpose of obtaining specific performance. Few of the many petitions to the chancellor that have survived from this period expressly request specific performance. ${ }^{305}$ Typically the petitioner asks that the defendant be examined, but otherwise the prayer for relief is quite vague-for example, that the defendant shall "do and receive that whicl conscience shall require."306 Usually the petitioner would allege lee was "without remedy at the Common Law."307 This meant that he was without any remedy at all at common law (because he was attempting to enforce an oral covenant), not that damages were madequate. In fact, some petitions contemplate the recovery of dainages in equity. ${ }^{308}$

Probably, lowever, specific performance was the normal relief given by medieval chancellors, whether or not it was requested. The assessment of damages was traditionally a function of the jury, ${ }^{300}$ and the chancellor had no power to empanel a jury. ${ }^{310}$ This did not mean that damages were never awarded in equity, ${ }^{311}$ but the easiest course was to order performance where possible so that the problem of assessing damages could be avoided.

In 1506 when the law courts decided to allow assumpsit against a seller who refused to convey land according to his promise, it was said that the buyer "will not need to sue a Subpoena." suggests that the common law courts, in enforcing oral covenants, were attempting to meet competition from equity. But Brooke, in abstracting this decision, adds: "[N]ote, however, that [the buyer] will have nothing but damages [im assumpsit], but by subpoena the Chancellor can compel [the seller] to execute the estate, or imprison him."313 The common law courts refused to follow equity to the extent of order-

also responsible for rent under the lease. Y.B. Mich. 10 Hen. 6, f. 11, pl. 38 (1431)

(per Strangeways, J.); 87 Sel. Soc. 219, No. 470.

303. J. AMES, supra note 3, at 248-49.

304. Anon., 10 Sel. Soc. 141, No. 142 (Ch. 1456).

305. Barbour, supra note 289, at 121-22.

306. A. KIRALFY, supra note 91, at 192.

307. Id. at 191.

308. Anon., 10 Sel. Soc. 44, No. 40 (Ch. 1398).

309. 3 BLACKSTONE *397-98.

310. Id. at $* 48$.

311. See A. FITZHERBert, supra note 26, at Sub pena 19.

312. Y.B. Mich. 21 Hen. 7, f. 41, pl. 66 (1506).

313. R. BROOKE, supra note 66 , at Action sur le case 72. 
ing specific performance. Instead they complained that "there are too many causes drawn into Chancery to be relieved there, which are more fit to be determined by trial at the common law." According to their view, if a seller refused to convey land, an action at law for damages was the "most proper" remedy. ${ }^{314}$ Although the common law courts could not prevent equity froin ordering specific performance, they could and did prohibit such decrees in lesser tribunals such as the Court of Requests. ${ }^{315}$

If too many causes were being drawn away froin the common law by plaintiffs who wanted specific performance, why didn't the common law courts satisfy this desire in order to preserve their jurisdiction? The answer suggested by Justice Coke is hardly convincing: to grant specific performance "would subvert the imtent of the covenantor, smce he intends it to be at his election either to pay damages" or to perform. ${ }^{316}$ However, a promisor when entering a contract usually gives little thought to the possibility that he will not perform, and thus has no real intent as to what the consequences of nonperformance should be. One could just as easily maintain the opposite-that if a promisor wishes to have the option to pay damages in lieu of performing he should stipulate for this privilege in the contract.

The history of the common law provided precedents for awarding specific performance of contracts. In actions of covenant brought by buyers or lessees of land, a successful plaintiff was usually put in possession of the land. ${ }^{317}$ It is sometimes suggested that the power of the courts to award land in actions of covenant disappeared in later law, ${ }^{318}$ but this is erroneous, for in the 18th century Blackstone says that a covenant to convey land is enforceable "by a special writ of covenant for a specific performance of the contract." ${ }^{\prime 319}$

Why then did the common law refuse to grant specific performance in the newer forms of action that arose in the 14th century? The prima facie answer seems to be that these forms of action were derived from trespass, and trespass was an action for dainages. Thus, in 1382 Chief Justice Belknap said that "ejectment is only an action of trespass by its nature and the plaintiff will not recover his term . . . He must sue by an action of covenant at common law to recover his term." 320

314. Gollew v. Bacon, 80 Eng. Rep. 809 (K.B. 1611).

315. Mollineux's Case, 82 Eng. Rep. 331 (K.B. 1626); Bromage v. Genning, 81 Eng. Rep. 540 (1616).

316. Bromage v. Genning, 81 Eng. Rep. 540 (1616).

317. Statute of Wales, 12 Edw. 1 , 10 (1285); BRActon's NOTE BOox, supra note 84 , at pl. 1739 (1226).

318. C. Frroor, supra note 67, at 259.

319. 3 Blackstone *157. See also F. Maitland, Equity and the Forms of ACTION 371 (1909).

320. A. FrTZHERBERT, supra note 26, at Eiectione firme 2. 
A lessee who had no specialty and could not therefore bring covenant had to seek equitable relief if he wanted the land, ${ }^{321}$ since ejectment gave only damages. By the end of the 15th century, however, lessees were allowed to recover the land in actions of ejectment at law..$^{\mathbf{3 2}}$ Blackstone is probably correct in suggesting that this change was inspired by the fact that equity had been giving specific relief to lessees. ${ }^{323}$ But the same transformation did not take place in assumpsit and trover. These remained actions for damages only, despite the example of equity. ${ }^{324}$

The law courts could have granted specific performance of contracts to convey property in the same way the chancellor did, by ordering the defendant to perform and by imprisoning him if he did not comply. The common law courts were certainly familiar with this type of decree and did not hesitate to resort to imprisonment to execute judgments. $^{325}$ If a defendant in an action of account refused to account he would be "put in irons." 326 In actions of detinue the court would order that the plaintiff recover the chattels, and imprisonment was available to ensure compliance. ${ }^{327}$ In this case, however, there was a problem: if the defendant had sold or destroyed the goods he could not comply with the order to deliver them. Therefore, the decree. in detinue was always conditional; if the plaintiff "could not have" the chattels, he was to recover their value as assessed by the jury. Ideally, the defendant should be coinpelled under such a decree to deliver the chattels if he still has them, or, as under the German Code of Civil Procedure, to swear "that he does not possess the thing and does not know where the thing is." ${ }^{\text {328 }}$ But the common law courts, since they could not examine the defendant, could not be certain whether or not he was able to comply with the order to dehiver. Therefore, in practice, the order in detinue gave the defendant the option of paying the assessed value of the goods instead of dehvering them to the plaimtiff. ${ }^{329}$ The common law courts would have encountered the same problein had they tried to transform trover or assumpsit into a remedy for specific performance of this type.

Instead of putting pressure on the defendant to perform his prom-

321. A. KIRALFY, supra note 91, at 115.

322. Id. at 112 ; F.N.B. $* 220 \mathrm{H}$.

323. 3 BLACKSTONE $* 200$.

324. Id. at $* 153$.

325. Id. at $* 414$.

326. Y.B. 18 \& 19 Edw. 3 (R.S.) 412 (1344-45).

327. Sutton v. Forster, 64 Sel. Soc. 56, 65 (Ex. 1483); Statute, 25 Edw. 3, stat. 5, c. 17 (1350).

328. Zivilprozessordnung [ZPO] \& 883 (C.H. Beck 1966).

329. 2 Bracton 292; Anon., 72 Eng. Rep. 221, 224 (K.B. 1505) (per Frowicke, C.J.); 3 BLACKSTONE $* 413$. 
ise, the courts could have resorted to direct action on the property covered by the contract. This procedure was employed in the action of ejectment in its later form. Ignoring the defendant, the court would issue a writ of possession "directed to the sheriff of the county, commanding him to give actual possession to the plaintiff of the land."330 This form of relief had the advantage that execution of judgment-unlike an equity decree ${ }^{331}$ - could not be frustrated by a contumacious defendant who was willing to endure imprisonment. Why then wasn't a writ of possession given for a plaintiff who recovered a judgment in assumpsit on a contract to buy land? Perhaps the reason was that the person in possession of the land at the time of the judgment might be a bona fide purchaser from the seller rather than the seller himself. As we have seen, the common law courts, unlike the chancellor, could not distinguish bona fide purchasers from other third persons, and so did not allow assumpsit to be brought against third persons at all. The saine difficulty would preclude issuing a writ of possession in assumpsit. Ejectment did not pose this problem because anyone who later bought the land would have had notice of the plaintiff's rights if the plaintiff had been in possession under his lease.

Because plaintiffs usually had to go into equity to obtain specific performance, and because equity traditionally gave relief only where the remedy at law was considered inadequate, "it caine to be that, in sharp contrast to the civil law approach, money damages were regarded as the norm and specific relief as the deviation." ${ }^{332}$ Thus, to some extent, the common law today differs from civil law in regarding specific relief as extraordinary because of its peculiar history. However, even in our system specific performance of contracts for the sale of land is the norm. ${ }^{333}$ And, in sales of personal property, where specific performance was historically regarded as exceptional, ${ }^{334}$ modern statutes allow plaintiffs to recover personal property in specie in cases where historically they would lave had to be content with dainages. ${ }^{335}$

The influence of history on contemporary law is clearer in regard to the form of trial used in actions to enforce contracts. There seems

330. 3 BLACKSTONE *412. Replevin operated in much the same way with respect to chattels. However, a problem was present if the chattels were removed from the county since the sheriff could act only within his own county. 2 BrActon 442-43; 3 BLACKSTONE *148-49.

331. See Reynolde v. Knott, 51 Sel. Soc. 147 (Ex. 1459).

332. Farnsworth, Legal Remedies for Breach of Contract, 70 Colum. L. Rev. 1145, 1154 (1970).

333. Id.

334. E.g., Cud v. Rutter, 24 Eng. Rep. 521 (Ex. 1719).

335. Common Law Procedure Act of 1854, 17 \& 18 Vict., c. 125; UNIFORM COMMERCIAL CODE $\$ 2-716$. 
to be no reason other than history for the fact that a plaintiff who seeks specific performance is not entitled to a jury trial. But since the seventh amendment applies only to "suits at common law,"

notwithstanding the fact that the Federal Rules of Civil Proccdure have abolished the distinction between 'actions at law' and 'suits in equity' in favor of a uniform system of procedure, we must nonetheless revert to that ancient distinction as a guideline in determining what issues are historically legal and therefore triable before a jury. ${ }^{\mathbf{3 3 0}}$

Modern law, both civil and common, refuses to order specific performance of contracts to render personal services. ${ }^{337}$ Less such reluctance appears in inedieval law. The Statute of Labourers provided that if a servant departed before the end of the term he had agreed to serve, he should "undergo imprisonment." 338 Apparently the draftsinen contemplated that a departing servant, like one covered by the compulsory service provisions who refused to serve, should be kept in prison until he found sureties for performing his service. ${ }^{\mathbf{3 3}}$ Occasionally in the 14th century, judgments against servants would provide that the plaintiff "shall have [the defendant] his servant, to serve him for the time aforesaid in the office aforesaid . . . and [the defendant] is delivered to [the plaintiff] by the court to serve him in the form aforesaid."340 However, in most cases the plaintiff only received damages. Presumably most employers preferred damages to the uncertain benefit of coerced labor from an unwilling servant.

In conclusion, the reluctance of the medieval common law courts to grant specific performance of contracts in all cases where it would be considered appropriate today seems to stein from their inability to examine the defendant. Specific performance came to be available for the most part only in equity. The principal contemporary significance of this fact is the denial of a right to jury trial in actions for specific performance.

\section{CoNCLUSION}

Despite the differences we have described annong the various forms of action used to enforce informal agreements in the later middle ages, the law of contract came to be regarded as a single entity. In the 16th century Samt Germain wrote that "it is not much argued in the laws of England what diversity is between a contract, a concord, a promise, a

336. Klein v. Shell Oil Co., 386 F.2d 659, 662 (8th Cir. 1967).

337. CaL. Crv. CODE $\$ 3390$ (1) (West 1970); The Case of Mary Clark, 1 Blackford 122 (Ind. 1821); ZPO $\$ 888$ (C.H. Beck 1966).

338. Statute of Labourers, 23 Edw. $3, \S 2$ (1349).

339. A. FITZHERBERT, supra note 26, at Laborers 56 (per Setone, C.J.K.B.); cf. GlanVille 98.

340. PutNaM, supra note 28, at 208-09. See also id. at app. 214. 
gift, a loan, or a pledge, a bargain, a covenant, or such other. For the intent of the law is to have the effect of the matter argued, and not the terms." "341 In making this statement, Saint Germain probably had in mind Roman law, in which it was "much argued" whether a given transaction constituted a sale, or lease, or one of the other forms of contract. $^{342}$ In the earlier middle ages the English law of contract was also compartmentalized. Different rules were applied in actions of debt, detinue, account, and covenant. For example, a specialty was required in covenant but not in debt. Actions of debt survived if the debtor died, but actions of account did not. In some situations wager of law was denied in account but allowed in detmue or debt. ${ }^{343}$ In the later middle ages, although the newer writs that appeared were also of different types, such as assumpsit, ejectment, and breach of warranty, the distinctions between these were not as clear cut as had been the distinctions between debt, detinue, covenant, and account. The carelessness of the Yearbooks about nomenclature illustrates this. The word "trespass" might be used to describe an innkeeper's writ, or one based on assumpsit, ejectment, breach of warranty, or the Statute of Labourers. Conversely, the same writ appears under different names; for example, what in later law was known as assumpsit, in the Yearbooks is variously called "deceit," "trespass," and "trespass on the case."

Although there were often disputes as to whether a newer writ, such as assumpsit, could be used im place of an older one, such as debt, ${ }^{344}$ rarely was there any controversy as to which of the newer writs applied in a particular situation. For example, if it was doubtful whether trespass or trespass on the case was appropriate to the facts, the question was usually resolved by allowing the plaintiff to bring either. ${ }^{345}$

This lack of concern for the respective boundaries of the newer forns of action is understandable because there were so few differences among thenr. Traditionally the rules applied in the various forms of action were markedly different with regard to jurisdiction, form of trial, type of process, and so forth. ${ }^{346}$ But such differences were largely absent in the various outgrowths of trespass that we have been discuss-

341. DOCTOR AND STUDENT 174-75.

342. E.g., INSTITUTES 3.23.2, 3.24.3, 3.24.4.

343. McGovern, supra note 1 , at 31-33, 45-46.

344. See text following note 230 supra.

345. See E. COKE, ON Litrleton *57a; Slade's Case, 76 Eng. Rep. 1072, 1078 (K.B. 1602); Bishop v. Viscountess Montague, 79 Eng. Rep. 42 (K.B. 1601); West v. Treude, 79 Eng. Rep. 764 (K.B. 1631). However, a strenuous effort was made in the 18th and 19th centuries to draw a clear line between trespass and case. C. FIFOor, supra note 67 , at 184-87.

346. F. MAITLAND, supra note 319 , at 296-98. 
ing. Whether the form of action was assumpsit, trover, or ejectment, the king's court had jurisdiction, trial was by jury, and the defendant was subject to arrest.

Insofar as differences did exist between the later writs, history had little to do with thein. For example, trover was held not to he against executors for a conversion by their testator, because "the cause of action is a tort," which died with the tortfeasor. ${ }^{347}$ But actions of assumpsit did survive the death of the promisor, even though assumpsit, like trover, arose from trespass. ${ }^{348}$ The common origin of the writs derived from trespass was also ignored in decisions regarding the propriety of joining different forms in a single action. A claim for breach of warranty could not be joined with a count in assumpsit. "One cannot join trespass and assumpsit in one action, or trover and assumpsit in one action, or deceit and assumpsit in one action, for that they are of separate natures, one grounded upon a right, the others upon torts." ${ }^{340}$ Certainly this distinction between trespass and assumpsit was not based on history, for in the 16th-century Register, writs that we would call assumpsit are listed under "Trespass." 350

These unhistorical distinctions, in turn, came to be ignored as courts became more hiberal in allowing a joinder of actions "of separate natures." In 1766 a defendant objected that the plaintiff's complaint had included "an action on the custom of the realm, which was founded in contract, and therefore cannot be joined with a count in trover which is a tort." But Chief Justice Wilmot disagreed:

This motion is after the merits have been tried, and a verdict found for the plaintiff, which the court will support if possible. It is objected that the first count is laid quasi ex contractu, and cannot be joined with trover; supposing it was so, yet I shall lay no great stress upon old cases to this point at this day, but $I$ think that the first count is laid to be ex delicto of the defendant . . . which may uudoubtedly be joined with Trover. ${ }^{351}$

Maitland, in a famous phrase, suggested that "the forms of action we have buried, but they still rule us froin their graves."362 To a large extent, the opposite is true. Even before the forms of action were officially buried, they had ceased to exercise a ruling influence on the

347. Hambly v. Trott, 98 Eng. Rep. 1136, 1138 (K.B. 1776).

348. McGovern, supra note 1 , at 54-56.

349. Bevingsay v. Ralston, 90 Eng. Rep. 32 (1682). See also Matthews v. The Carrier of Tiverton Hopping, 83 Eng. Rep. 1281 (K.B. 1665); Bage v. Bromuel, 83 Eng. Rep. 596 (K.B. 1684).

350. REGISTRUM OMNIUM BREVIUM f. 105V (1595).

351. Dickon v. Clifton, 2 Wilson 319, 321 (1766). See also Kightly v. Birch, 105 Eng. Rep. 480 (1814).

352. F. MAITLAND, supra note 319 , at 296. 
development of the law. If the propositions advanced in this Article are sound, we are much less the prisoners of history than is commonly supposed. 